\title{
PUTUSAN PENGADILAN PIDANA SEBAGAI DASAR PENGAJUAN GUGATAN PERBUATAN MELAWAN HUKUM TERKAIT PELAKSANAAN UANG PENGGANTI
}

\author{
Sri Laksmi Anindita* dan Lazuardi Adnan** \\ * Pengajar Bidang Studi Hukum Acara Fakultas Hukum Universitas Indonesia \\ ** Klinik Hukum Fakultas Hukum Universitas Indonesia \\ Korespondensi: lazadnanpane@gmail.com. \\ Naskah dikirim: 21 Oktober 2016 \\ Naskah diterima untuk diterbitkan: 15 Maret 2017
}

\begin{abstract}
Since Indonesia has known and enforced the concept of tort, an act regarded as tort is not only actions contrary to the law, but an act that violates the principles of propriety, the principles of thoroughness and cautionary principle also included in tort. This is due to the fact that the onrechtmatige daad concept is wider than onwetmatige daad concept. Around 2010, it was found that the act of not fulfilling the decision of court which has binding power associated for compensatory money in cases of corruption becomes the basis of a tort lawsuit, where the problem is that court verdict is not a main legal source for countries which adopt civil law such as Indonesia. Therefore, this paper will explain more on regulation regarding lawsuit filing pursuant to Article 1365 Civil Code, particularly in terms of not implementing court decisions with binding power related to the fulfillment of payment of compensation in corruption.
\end{abstract}

Keyword: Tort (onrechtmatige daad), court verdict, execution.

\begin{abstract}
Abstrak
Sejak Indonesia mengenal dan memberlakukan konsep perbuatan melawan hukum, suatu perbuatan dianggap sebagai perbuatan melawan hukum tidak hanya perbuatan yang bertentangan dengan undang-undang, akan tetapi perbuatan yang melanggar asas kepatutan, asas ketelitian dan asas kehatihatian juga termasuk dalam perbuatan melawan hukum. Itu karena, konsep onrechtmatige daad lebih luas dari pada konsep onwetmatige daad. Sekitar tahun 2010, ditemukan bahwa perbuatan tidak memenuhi isi putusan pengadilan yang telah berkekuatan hukum tetap terkait pembayaran uang pengganti pada kasus tindak pidana korupsi dijadikan dasar gugatan perbuatan melawan hukum, padahal putusan bukan sumber hukum utama bagi negara yang menganut sistem hukum civil law seperti Indonesia. oleh karena itu dalam penulisan ini akan menjelaskan lebih lanjut mengenai pengaturan pengajuan gugatan berdasar Pasal 1365 KUHPerdata, khususnya dalam hal
\end{abstract}


tidak melaksanakan putusan pengadilan yang berkekuatan hukum tetap terkait pemenuhan pembayaran uang pengganti dalam tindak pidana korupsi.

Kata kunci: Perbuatan Melawan Hukum (onrechtmatige daad), Putusan Pengadilan, Eksekusi

\section{Pendahuluan}

\section{Latar Belakang}

Kaedah hukum merupakan ketentuan atau pedoman tentang apa yang seyogyanya atau seharusnya dilakukan, yang di dalamnya berisi kenyataan normatif (das sollen) dan bukan berisi kenyataan alamiah atau peristiwa konkrit (das sein). ${ }^{1}$ Bicara soal hukum yang penting bukanlah apa yang terjadi, tetapi apa yang seharusnya terjadi. Hukum baru muncul ketika ada beberapa kepentingan (seperti kepentingan sosial, kepentingan politik, kepentingan ekonomi, dan lain-lain) yang berbenturan. Hukum dapat berperan sebagai pencegah terhadap masalah yang akan timbul, maupun mengatasi masalah yang sedang terjadi. Misalnya, jika dua orang atau lebih terlibat dalam suatu perjanjian, kemudian salah satu pihak ada yang melanggar perjanjian. Pihak yang melanggar perjanjian dapat diajukan gugatan perdata dengan dasar wanprestasi. Beda halnya terhadap seseorang yang mengalami kerugian atas perbuatan orang lain tanpa didasari suatu perjanjian, maka orang yang mendapat kerugian itu dapat mengajukan gugatan perdata dengan dasar perbuatan melawan hukum.

Konsep perbuatan melawan hukum yang diterapkan di Indonesia adalah konsep onrechtmatige daad, bukan onwetmatige daad. Belanda memberlakukan konsep onrechtmatige daad saat menjajah Indonesia dan karena pengaruh kolonialisme, Indonesia menggunakan hukum negara penjajahnya (asas konkordansi), sehingga konsep itu masih berlaku hingga saat ini. ${ }^{2}$ Di Indonesia, dasar pengajuan gugatan perbuatan melawan hukum adalah perbuatan manusia yang melanggar peraturan perundang-undangan dan/atau melanggar asas kepatutan, asas ketelitian, dan asas kehati-hatian. Indonesia pernah menjadi negara jajahan eropa daratan yang menganut sistem hukum eropa kontinental (civil law) sehingga sumber hukumnya adalah undangundang sebagai hukum positif yang berlaku. ${ }^{3}$

Sekitar tahun 2010 telah ditemukan bahwa adanya gugatan perdata dengan putusan pengadilan sebagai dasar pengajuan gugatan perbuatan melawan hukum. Pada pokoknya putusan pengadilan tersebut berkaitan dengan delik tindak pidana korupsi. Beberapa putusan pengadilan yang dimaksud adalah putusan nomor 22/Pdt.G/2010/PN.Ung yang dikeluarkan oleh Pengadilan Negeri Kabupaten Semarang di Ungaran pada tanggal 10 Agustus 2012, putusan nomor 116/Pdt.G/2013/PN.Mtr yang dikeluarkan oleh

${ }^{1}$ Sudikno Mertokusumo, Mengenal Hukum Suatu Pengantar, cet. 4, (Yogyakarta: Liberty, 2008), hlm. 15.

${ }^{2}$ Tim Pengajar Pengantar Hukum Indonesia, Materi Ajar Pengantar Hukum Indonesia (Depok: Fakultas Hukum Universitas Indonesia, 2012), hlm. 23.

${ }^{3}$ Ibid. hlm. 31-32. 
Pengadilan Negeri Mataram pada tanggal 2 Oktober 2013, dan putusan nomor 24/Pdt.G/2013/PN.PRA yang telah dkeluarkan oleh Pengadilan Negeri Praya pada tanggal 4 September 2013. Ketiga putusan pengadilan tersebut memiliki dasar pengajuan gugatan yang sama, yakni gugatan perbuatan melawan hukum dengan dasar perbuatan tidak melaksanakan putusan pengadilan yang telah berkekuatan hukum tetap. Tergugat pada ketiga putusan pengadilan di atas adalah terpidana tindak pidana korupsi yang tidak melaksanakan pembayaran uang pengganti sebagai pidana tambahan atas tindak pidana korupsi yang telah mereka lakukan. Jaksa Penuntut Umum mengajukan gugatan perbuatan melawan hukum kepada mereka akibat tidak dilaksanakannya pembayaran uang pengganti. Berdasarkan latar belakang dan sedikit penjelasan mengenai putusan di atas, penulis tertarik untuk menulis dan mengkaji ke dalam suatu karya ilmiah yang berjudul Putusan Pengadilan Pidana Sebagai Dasar Pengajuan Gugatan Perbuatan Melawan Hukum Terkait Pelaksanaan Uang Pengganti (Studi Kasus: Putusan Nomor 22/Pdt.G/2010/PN.Ung; Putusan Nomor 116/Pdt.G/2013/PN.Mtr; Putusan Nomor 24/Pdt.G/2013/PN.Pra)

\section{Pokok Permasalahan}

1. Apakah dasar pengajuan gugatan Perbuatan Melawan Hukum yang berlaku selama ini di Indonesia?

2. Apakah tidak dilaksanakannya suatu Putusan Pengadilan Pidana tentang pelaksanaan uang pengganti dalam tindak pidana korupsi yang telah berkekuatan hukum tetap dapat menjadi dasar gugatan perbuatan melawan hukum (onrechtmatige daad)?

3. Apakah tidak melakukan pembayaran uang pengganti berdasarkan putusan yang telah berkekuatan hukum tetap (putusan nomor 73/Pid.B/2002/PN.Ung tanggal 23 Oktober 2002, putusan nomor 718 $\mathrm{K} / \mathrm{Pid} / 1985$ tanggal 25 Juni 1985, dan putusan nomor $107 \mathrm{~K} / \mathrm{Pid} / 1994$ tanggal 29 Mei 1994) dapat menjadi dasar pengajuan gugatan perbuatan melawan hukum (onrechtmatige daad)?

\section{Metode Penelitian}

Penulisan ini menggunakan bentuk penelitian yuridis normatif ${ }^{4}$, yakni penelitian yang dilakukan terhadap hukum positif tertulis maupun tidak tertulis. Tipologi penelitian dari sudut sifatnya merupakan penelitian deskriptif. Penelitian yang dilakukan dalam rangka penulisan skripsi ini adalah penelitian hukum normatif, dalam hal ini Penulis menggunakan bahan pustaka atau data sekunder sebagai berikut:

1. Bahan hukum primer, yaitu bahan-bahan hukum yang mengikat. Dalam penulisan ini bahan-bahan hukum primer yang digunakan diantaranya adalah peraturan perundang-undangan, seperti Kitab Undang-Undang Hukum Perdata, Kitab Undang-Undang Hukum Acara Perdata (Herzien Inlandsch Reglement/Reglemen Indonesia Yang Diperbaharui (R.I.B.)),

4 Sri Mamudji et.al., Metode Penelitian dan Penulisan Hukum (Jakarta: Badan Penerbit Fakultas Hukum Universitas Indonesia, 2005), hlm. 9. 
Rechtreglement voor de Buitengewesten ( $\mathrm{RBg})$, Reglement of de Rechtsvordering (Rv.), dan peraturan perundang-undangan lain yang berkaitan dengan penelitian ini;

2. Bahan hukum sekunder, yaitu bahan-bahan hukum yang menjelaskan bahan hukum primer, seperti karya-karya ilmiah dari para ahli hukum;

3. Bahan hukum tersier, yaitu bahan-bahan hukum yang memberikan petunjuk maupun penjelasan terhadap bahan hukum primer dan bahan hukum sekunder, seperti kamus hukum dan kamus umum Belanda Indonesia yang digunakan dalam penulisan ini.

Pendekatan yang digunakan dalam mengolah data yang berkaitan dengan penelitian ini adalah pendekatan kualitatif karena pengolahan data tidak dilakukan dengan mengukur data sekunder terkait, tetapi menganalisis secara deskriptif data tersebut. Proses analisis data sekunder yang diperoleh dilakukan dengan menelaah peraturan perundang-undangan, teori-teori hukum, dan artikel-artikel yang terkait dengan pokok permasalahan dalam penelitian ini untuk kemudian dicari kesesuaian antara satu dengan yang lainnya. Pada pendekatan kualitatif, tata cara penelitian menghasilkan data deskriptif analitis, yaitu apa yang dinyatakan oleh sasaran penelitian yang bersangkutan secara tertulis, lisan, dan perilaku nyata, ${ }^{5}$ Pendekatan kualitatif seringkali disebut sebagai pendekatan dengan pemahaman yang mendalam dan tuntas karena pendekatan kualitatif mempertanyakan suatu objek secara mendalam dan tuntas.

\section{Hasil dan Temuan}

\section{Perbuatan Melawan Hukum}

Perbuatan melawan hukum sudah dikenal sejak manusia mengenal hukum dan telah dimuat secara tertulis yang pernah dikenal sejarah, yaitu Hukum Kode Hammurabi (Code of Hammurabi) yang berlaku di masyarakat Babylonia pada tahun $1780 .{ }^{6}$ Hukum kode Hammurabi merupakan salah satu hukum tertulis pertama dunia, yang juga menganut Lex Talionis (hukum pembalasan). Kitab tersebut mengatur mengenai akibat hukum seseorang yang melakukan perbuatan melanggar hukum. Mengenai terminologi "perbuatan melawan hukum" itu sendiri merupakan terjemahan dari kata onrechtmatige daad, yang diatur dalam KUHPerdata Buku III tentang Perikatan, Pasal 1365 sampai dengan Pasal 1380, atau dalam bahasa Inggris disebut dengan istilah "tort". Kata tort itu sendiri sebenarnya hanya berarti "salah" (wrong). Akan tetapi khususnya dalam bidang hukum, kata tort itu berkembang sedemikian rupa sehingga berarti kesalahan perdata yang bukan berasal dari wanprestasi kontrak. Jadi serupa dengan pengertian perbuatan melawan hukum (onrechmatige daad) dalam sistem hukum Belanda atau di negara-negara Eropa Kontinental lainnya. ${ }^{7}$

${ }^{5}$ Ibid., hlm. 67.

${ }^{6}$ Ahmadi Miru, Hukum Perdata Materiil dan Formil, (Jakarta: United States Agency for International Development (USAID), 2013), hlm. 338.

7 Munir Fuady, Perbuatan Melawan Hukum (Pendekatan Kontemporer), (Bandung: PT Citra Aditya Bakti, 2002), hlm. 2. 
Sejarah perbuatan melawan hukum di Eropa dimulai dari negara Perancis, dimana Perancis merupakan negara terpusat ${ }^{8}$ selama berabad-abad sebelum civil code dibuat pada tahun $1804 .{ }^{9}$ Civil code, merupakan undangundang Perancis yang dibuat oleh raja Napoleon Bonaparte pada masa kekuasaannya tahun 1799. Civil code merupakan cikal bakal tort (perbuatan melawan hukum) di Perancis. ${ }^{10}$ Struktur perbuatan melawan hukum di Perancis agak sederhana, dimana para perancang code civil hanya memberikan beberapa ketentuan yang sangat singkat dan umum pada Pasal 1382 hingga Pasal 1386 civil code. Ketentuan lama perbuatan melawan hukum berada pada Pasal 1382 Civil code Perancis yang berbunyi:

"Tout fait quelcongue de I'homme, qui cause un dommage, oblige celui par la faute du quel il est arrive, a le reparer" ('Any act whatever of man which causes damage to another obliges him by whose fault in occurred to make reparation') 11

Ketentuan di atas menjelaskan bahwa setiap perbuatan manusia yang mengakibatkan kerusakan, mewajibkan dia karena salahnya memperbaiki kerusakan tersebut. Pasal 1382 Code civil mensyaratkan adanya unsur kesalahan dari perbuatan yang dilakukan.

Pada tahun 1989 Civil code tersebut berlaku di Negeri Belanda. Setelah kemerdekaan Negeri Belanda dari Perancis, maka dibuatlah KUHPerdata Belanda yang isinya berasal dari code civil, dimana Pasal 1382 code civil Napoleon akhirnya menjadi Pasal 1401 Burgerlijk Wetboek Belanda, yang berbunyi:

"Elke onrechtmatige daad, waardoor aan een ander schade wordt toegebragt, stelt dengene door wiens. Schuld die scade veroorzaakt is in deverpligting om dezel ve tevergoeden"

Secara umum, isi ketentuan di atas hampir serupa dengan dengan code civil Napoleon, karena Pasal 1401 Burgerlijk Wetboek berasal dari code civil. Pada intinya pasal di atas mengatakan bahwa setiap perbuatan melawan hukum (onrechtmatige daad) yang mengakibatkan kerusakan mewajibkan si pelaku pembuat kerusakan untuk memperbaikinya. Namun dapat dilihat bahwa terdapat perbedaan diantara dua pasal di atas, dimana pada code civil disebutkan bahwa perbuatan itu adalah perbuatan manusia, sedangkan pada KUHPerdata Belanda yang lama tidak ada unsur perbuatan manusia, sehingga memberi kemungkinan selain manusia yang mengakibatkan kerusakan, wajib untuk mengganti atas kerusakan itu, misalnya hewan yang membuat kerusakan

\footnotetext{
${ }^{8}$ Sampai akhir abad ke-17, hukum yang berlaku di Perancis adalah hukum Romawi, hukum Canon, dan hukum Adat. Sejak saat itu pengacara yang berpengaruh seperti Domat, Pothier, dan Bourjin berkontribusi terhadap perkembangan hukum Perancis sebagai sistem nasional harmonis. Sehingga banyak bangsa-bangsa di Eropa meniru sistem hukum Perancis di bangsanya.

${ }^{9}$ Van Dam, European Tort Law, (New York: Oxford University Press, 2006), hlm. 41.$$
{ }^{10} \mathrm{Ibid} \text {. }
$$$$
11 \quad \text { Code Civil, Article 1382, }
$$
<https://www.legifrance.gouv.fr/affichCodeArticle.do?cidTexte=LEGITEXT0

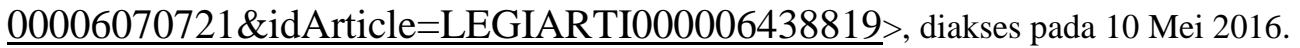


mewajibkan kepada pemiliknya untuk mengganti kerusakan itu. Pada mulanya ketentuan Pasal 1401 Burgerlijk Wetboek Belanda diterapkan secara sangat sempit oleh Pengadilan Negeri Belanda. Suatu tindakan atau perbuatan baru dianggap sebagai perbuatan melawan hukum, hanya apabila ada suatu ketentuan yang mewajibkan dan/atau melarang orang perorangan atau badan hukum tertentu untuk melakukan suatu tindakan. ${ }^{12}$

Pada tahun 1919, Hoge Raad Belanda dalam putusannya tanggal 31 Januari 1919 menyatakan bahwa perkataan "hukum" dalam perbuatan melawan hukum telah ditafsirkan secara lebih luas, hingga tidak hanya meliputi pada undang-undang atau peraturan atau ketentuan tertulis yang berlaku, melainkan juga pada kepatutan dan kesusilaan. Putusan Hoge Raad tersebut adalah terhadap kasus Lindenbaum versus Cohen. Pada putusan tingkat kasasi, Hoge Raad menyatakan bahwa yang dimaksud dengan perbuatan melawan hukum bukan hanya melanggar undang-undang yang tertulis seperti yang ditafsirkan saat itu, melainkan juga termasuk ke dalam pengertian perbuatan melawan hukum adalah setiap tindakan: ${ }^{13}$

1. Bertentangan dengan hak orang lain, atau

2. bertentangan dengan kewajiban hukum si pelaku, atau

3. bertentangan dengan kesusilaan (geode zeden), atau

4. bertentangan dengan keharusan yang harus diindahkan dalam pergaulan masyarakat mengenai orang lain atau benda.

Konsep perbuatan melawan hukum dibawa Belanda ke Indonesia dan masih dipakai hingga saat ini. Kitab Undang-Undang Hukum Perdata tidak mengatur dengan tegas mengenai pengertian dari perbuatan melawan hukum. Pasal 1365 KUHPerdata hanya memberikan dasar pengajuan ganti kerugian berdasarkan perbuatan melawan hukum. Menurut Wirjono Prodjodikoro yang menggunakan istilah perbuatan melanggar hukum, perbuatan melanggar hukum adalah perbuatan yang mengakibatkan kegoncangan dalam neraca keseimbangan dari masyarakat, dan kegoncangan tersebut tidak hanya terdapat apabila peraturan-peraturan hukum dalam suatu masyarakat dilanggar, melainkan juga, apabila peraturan-peraturan kesusilaan, keagamaan dan sopan santun dalam masyarakat dilanggar. ${ }^{14}$ Selain itu, R. Wirjono Projodikoro juga mengartikan kata onrechtmatige daad sebagai perbuatan melanggar hukum. ${ }^{15}$ Menurutnya perkataan "perbuatan" dalam rangkaian kata-kata "perbuatan melanggar hukum" dapat diartikan secara positif dan negatif, yaitu meliputi juga hal yang orang dengan berdiam diri saja dapat dikatakan melanggar hukum karena menurut hukum seharusnya orang itu bertindak. Perbuatan negatif yang dimaksudkan bersifat "aktif" yaitu orang yang diam saja, baru dapat dikatakan melakukan perbuatan hukum, kalau ia sadar, bahwa ia dengan diam saja adalah melanggar hukum, maka yang bergerak bukan tubuhnya

12 Moegni Djojodirdjo, Perbuatan Melawan Hukum, (Jakarta: Pradnya Paramita, 1979), hlm. 21.

${ }^{13}$ Ibid., hlm. 35.

${ }^{14}$ Wirjono Prodjodikoro, Perbuatan melawan Hukum, (Bandung: Sumur Bandung, 1993), hlm. 13.

${ }^{15}$ Ibid., hlm 8 .. 
seseorang itu, melainkan pikiran dan perasaannya. Jadi, unsur bergerak dari pengertian "perbuatan" kini pun ada. Perkataan "melanggar" dalam rangkaian kata-kata "perbuatan melanggar hukum" yang dimaksud bersifat aktif, maka menurut beliau perkataan yang paling tepat untuk menerjemahkan onrechtmatige daad ialah perbuatan melanggar hukum karena istilah perbuatan melanggar hukum menurut Wirjono Prodjodikoro ditujukan kepada hukum yang pada umumnya berlaku di Indonesia dan yang sebagian terbesar merupakan hukum adat. Lain halnya dengan istilah yang digunakan oleh M.A. Moegni Djojodirjo, dalam kata "melawan" melekat sifat aktif dan pasif. Sifat aktif dapat dilihat apabila dengan sengaja melakukan sesuatu perbuatan yang menimbulkan kerugian pada orang lain, jadi sengaja melakukan gerakan sehingga nampak dengan jelas sifat aktifnya dari istilah "melawan tersebut". Sebaliknya apabila ia diam saja atau dengan sengaja diam saja atau dengan perkataan lain apabila ia dengan sikap pasif saja sehingga menimbulkan kerugian pada orang lain, maka ia telah "melawan" tanpa harus menggerakkan badannya. ${ }^{16}$

Hukum sebagai kumpulan peraturan atau kaedah mempunyai isi yang bersifat umum dan normatif, umum karena berlaku bagi setiap orang dan normatif karena menentukan apa yang seyogyanya dilakukan, apa yang tidak boleh dilakukan atau harus dilakukan serta menentukan bagaimana caranya melaksanakan kepatuhan pada kaedah-kaedah. Jika melihat pada sumber hukum, dimana bila dilihat dari bentuknya, sumber hukum dapat dibagi menjadi sumber hukum tertulis dan sumber hukum tidak tertulis. Contoh sumber hukum tertulis adalah undang-undang, putusan pengadilan atau yurisprudensi, dan perjanjian internasional. Sedangkan contoh sumber hukum tidak tertulis adalah kebiasaan dan hukum adat. ${ }^{17}$ Selain itu, menurut Algra ${ }^{18}$ membagi sumber hukum menjadi sumber hukum materiil dan sumber hukum formil. Sumber hukuum materiil ialah tempat dari mana materi hukum itu diambil. Sumber hukum materiil ini merupakan faktor yang membantu pembentukan hukum, misalnya: hubungan sosial, hubungan kekuatan politik, situasi sosial ekonomis, tradisi yang kesemuanya obyek studi penting bagi sosiologi hukum.

Bagi orang yang mempelajari hukum sebagai ilmu hukum positif yaitu hukum yang berlaku di dalam masyarakat, masalah sumber hukum dalam arti materiil merupakan hal yang kurang bahkan tidak relevan pada usaha untuk memahami dan menguasai hukum positif. Dengan kata lain bagi orang yang hendak mempelajari hukum positif, persoalan sumber hukum dalam arti materiil merupakan persoalan yang meta-yuridis atau persoalan yang terletak di luar hukum. ${ }^{19}$ Sumber hukum formil merupakan tempat atau sumber dari mana suatu peraturan memperoleh kekuatan hukum yang berkaitan dengan bentuk

\footnotetext{
16 Moegni Djojodirdjo, Perbuatan Melawan Hukum, (Jakarta: Pradnya Paramita, 1979), hlm. 13.

${ }^{17}$ Ibid., hlm. 21.

${ }^{18}$ Ibid., hlm. 82.

19 Mochtar Kusumaatmadja dan Arief Sidharta, Pengantar Ilmu Hukum, cet. 2, (Bandung: PT. Alumni, 2009), hlm. 59.
} 
atau cara yang menyebabkan peraturan hukum itu formil berlaku. ${ }^{20}$ Sumber hukum dalam arti formil bertalian dengan masalah atau persoalan dimanakah kita bisa mendapatkan ketentuan-ketentuan atau kaidah-kaidah yang mengatur kehidupan manusia dalam masyarakat. Sumber hukum formil dapat berupa undang-undang; kebiasaan (termasuk hukum adat); putusan pengadilan (yurisprudensi); traktat atau perjanjian; dan doktrin. ${ }^{21}$ Sehubungan dengan penulisan ini, maka putusan pengadilan akan dibahas lebih lanjut. Portalis yang merupakan salah seorang perancang code civil mengatakan bahwa legislator dalam membuat undang-undang hanya memberikan pengaturan secara umum, yaitu mempertimbangkan manusia secara keseluruhan bukan sebagai kumpulan individu, sedangkan magistrats yang dalam hal ini merupakan sosok hakim sebagai pelaksana undang-undang (dalam membuat putusan pengadilan), berkaitan sehari-hari dengan penerapan undang-undang yang senantiasa baru. ${ }^{22}$ Putusan pengadilan bukanlah penerapan suatu teks undang-undang secara tepat, melainkan lebih merupakan rangkaian beberapa teks yang membimbing ke arah putusan meskipun tidak lagi berisi teks-teks itu. ${ }^{23}$ Putusan pengadilan merupakan produk yudikatif, yang berisi kaedah atau peraturan hukum yang mengikat pihak-pihak yang bersangkutan atau terhukum. Jadi putusan pengadilan hanya mengikat orang-orang tertentu saja dan tidak mengikat setiap orang secara umum seperti undang-undang. Oleh karena putusan berisi kaedah hukum, maka dapat dikatakan putusan pengadilan adalah hukum. ${ }^{24}$ Putusan pengadilan adalah hukum sejak dijatuhkan sampai dilaksanakan. Sejak dijatuhkan, putusan pengadilan mempunyai kekuatan mengikat bagi para pihak yang berperkara, mengikat para pihak untuk mengakui eksistensi putusan tersebut. Putusan pengadilan mempunyai kekuatan berlaku untuk dilaksanakan sejak putusan itu memperoleh kekuatan hukum yang tetap. ${ }^{25}$ Adapun yang menjadi perbedaan dengan undang-undang adalah:

1. Bahwa putusan pengadilan berisi peraturan-peraturan yang bersifat konkrit karena mengikat orang-orang tertentu saja, sedangkan undangundang berisi peraturan-peraturan yang bersifat abstrak/umum karena mengikat setiap orang;

2. Bahwa putusan pengadilan terdiri dari bagian yang memuat identitas para pihak yang bersangkutan, konsiderans atau pertimbangan yang memuat alasan-alasan yang digunakan sebagai dasar putusan, dan

\footnotetext{
${ }^{20}$ Mertokusumo. Mengenal Hukum Suatu Pengantar, cet. 4, (Yogyakarta: Liberty, 2008), hlm. 83.

${ }^{21}$ Ibid., hlm. 60.

${ }^{22}$ Sri Laksmi Anindita, "Keyakinan Hakim Dalam Menjatuhkan Putusan Perkara Pidana," dalam Praperadilan dan Perkembangannya Dalam Hukum Acara Pidana Indonesia, ed. Disriani Latifah Soroinda, (Depok: Badan Penerbit FHUI, 2016), hlm 141.

${ }^{23}$ Ibid.

${ }^{24}$ Mertokusumo, Mengenal Hukum Suatu Pengantar, cet. 4, (Yogyakarta: Liberty, 2008), hlm 112.

${ }^{25}$ Ibid.
} 
Putusan Pengadilan Pidana Sebagai dasar Pengajuan Gugatan PMH, Sri Laksmi Anindita

diktum atau amar putusan; sedangkan undang-undang itu terdiri dari konsiderans dan diktum. ${ }^{26}$

Ketentuan mengenai perbuatan melawan hukum di Indonesia terdapat pada Pasal 1365 KUHPerdata. Dari ketentuan tersebut dapat diketahui bahwa suatu perbuatan dikatakan melawan hukum apabila ia memenuhi unsur-unsur yang ada dalam KUHPerdata. Jika unsur-unsur Pasal 1365 KUHPerdata dipenuhi secara kumulatif maka perbuatan tersebut dapat dikategorikan sebagai perbuatan melawan hukum. Menurut Hoffman, untuk adanya suatu perbuatan melawan hukum harus dipenuhi empat unsur, yaitu:

1. Er moett een daad zijn verricht; (harus ada yang melakukan perbuatan)

2. Die Daad moet onrechtmatig zijn; (perbuatan itu harus melawan hukum)

3. De daad moet aan een ander schade heb bentoege bracht; (perbuatan itu harus menimbulkan kerugian pada orang lain)

4. De daad moet aan schuld zijn te wijten; (perbuatan itu karena kesalahan yang dapat ditimpakan kepadanya). ${ }^{27}$

Sama halnya dengan Hoffman, Mariam Darus Badrulzaman mengatakan bahwa syarat-syarat yang harus ada untuk menentukan suatu perbuatan sebagai perbuatan melawan hukum adalah sebagai berikut:

1. Harus ada perbuatan;

2. Perbuatan itu harus melawan hukum;

3. Ada kerugian;

4. Ada hubungan sebab akibat antara perbuatan melawan hukum itu dengan kerugian;

5. Ada kesalahan. (schuld $)^{28}$

\section{Penggolongan Putusan Pengadilan}

Berdasarkan Pasal 185 ayat (1) H.I.R. dan Pasal 196 ayat (1) Rbg. putusan dibedakan menjadi dua, yaitu putusan sela dan putusan akhir. Putusan sela atau putusan bukan putusan akhir biasa disebut dengan istilah-istilah: "putusan antara", "tussen-vonnis", "putusan sementara" atau "interlocutoir vonnis" yaitu putusan dijatuhkan oleh hakim sebelum memutus pokok perkaranya dimaksudkan agar mempermudah kelanjutan pemeriksaan perkara. $^{29}$ Pada praktiknya, putusan sela harus diucapkan oleh ketua Majelis/Hakim tunggal dalam persidangan terbuka untuk umum dan dicatat

26 Ibid.

${ }^{27}$ Rosa Agustina, Perbuatan Melawan Hukum, cet I, (Jakarta: Program Pascasarjana Fakultas Hukum Universitas Indonesia, 2003), hlm. 36.

${ }^{28}$ Mariam Darus Badrulzaman, KUH Perdata Buku III Hukum Perikatan dengan penjelasan, (Bandung: Alumni, 1996), hlm 147.

29 Lilik Mulyadi, Hukum Acara Perdata: Menurut Teori \& Praktek Peradilan Indonesia, (Jakarta: Djambatan, 1999), hlm. 211. 
dalam berita acara persidangan, sebagaimana diatur dalam Pasal 185 ayat (1) H.I.R. dan Pasal 196 ayat (1) Rbg. Adapun putusan sela dapat berupa:

a. Putusan Preparatoir

Putusan preparatoir merupakan salah satu spesifikasi yang terkandung dalam putusan sela, yang dijatuhkan oleh hakim guna mempersiapkan dan mengatur pemeriksaan perkara. Sifat dasar dari putusan ini adalah tidak mempengaruhi pokok perkara itu sendiri. Misalnya putusan yang menetapkan bahwa gugatan balik (gugatan dalam reconventie) tidak akan diputus bersamasama dengan gugatan dalam conventie, ${ }^{30}$ atau sebelum hakim memulai pemeriksaan, lebih dahulu menjatuhkan putusan tentang tahap-tahap proses atau jadwal persidangan. Umpamanya pembatasan tahap jawab-menjawab atau replique-duplique dan tahap pembuktian. Akan tetapi, dalam praktik hal ini jarang terjadi. Proses pemeriksaan berjalan dan berlangsung sesuai dengan kebijakan hakim, yaitu dengan memperhitungkan tenggang pemunduran persidangan oleh hakim tanpa lebih dahulu ditentukan tahap-tahapnya. ${ }^{31}$

b. Putusan Interlocutoir

Putusan interlocutoir merupakan putusan sela yang dijatuhkan oleh hakim dengan amar berisikan perintah pembuktian dan dapat mempengaruhi pokok perkara. Contoh putusan Interlocutoir antara lain:

i. Putusan yang memerintahkan pendengaran keterangan ahli, berdasarkan Pasal 154 H.I.R. Dalam hal hakim secara ex officio maupun atas permintaan salah satu pihak, menganggap perlu mendengar pendapat ahli yang kompeten menjelaskan hal yang belum terang tentang masalah yang disengketakan;

ii. Putusan yang memerintahkan pemeriksaan setempat (descente), berdasarkan Pasal 153 H.I.R dan Pasal 180 Rbg. Dalam hal hakim berpendapat atau atas permintaan salah satu pihak, perlu dilakukan pemeriksaan setempat maka pelaksanaannya dilakukan oleh Hakim Komisaris dan Panitera. Akan tetapi, pasal ini ditiadakan oleh karena sekarang Pengadilan Negeri hanya terdiri dari seorang hakim. ${ }^{32}$ Berdasarkan pengamatan dari Mahkamah Agung, bahwa perkara-perkara yang telah berkekuatan hukum tetap tidak dapat dieksekusi karena obyek perkara tidak sesuai dengan dictum putusan, baik mengenai letak, luas, dan batas-batas obyek perkara, sebelumnya tidak pernah dilakukan Pemeriksaan Setempat atas obyek perkara, maka Mahkamah Agung telah mengeluarkan S.E.M.A. Nomor 7 Tahun 2001 tentang Pemeriksaan Setempat. Dari S.E.M.A tersebut, terhadap perkara yang obyek sengketanya tanah, maka wajib untuk dilakukan pemeriksaan setempat.

\footnotetext{
${ }^{30}$ Ibid., hlm. 210.

31 M. Yahya Harahap, Hukum Acara Perdata Tentang Gugatan, Persidangan, Penyitaan, Pembuktian, dan Putusan Pengadilan, cet. III, (Jakarta: Sinar Grafika, 2005), hlm. 897.

${ }^{32}$ Reglemen Indonesia yang Diperbaharui [Herziene Indonesisch Reglement], Stb. 1941 No. 44, disusun oleh M. Karjadi, (Bogor: Politeia, 1979), psl. 153.
} 
iii. Putusan yang memerintahkan pengucapan atau pengangkatan sumpah baik sumpah penentu atau sumpah tambahan berdasarkan Pasal 155 H.I.R. dan Pasal 1929 KUHPerdata;

iv. Putusan yang memerintahkan pemanggilan saksi berdasarkan Pasal 139 H.I.R., yakni saksi yang diperlukan penggugat atau tergugat, tetapi tidak dapat menghadirkannya berdasarkan Pasal 121 H.I.R., pihak yang berkepentingan dapat meminta kepada hakim agar saksi tersebut dipanggil secara resmi oleh juru sita;

v. Dapat juga putusan yang memerintahkan pemeriksaan pembukuan perusahaan yang bersengketa oleh akuntan publik yang independen. ${ }^{33}$

c. Putusan Incidenteel

Putusan incidenteel adalah salah satu jenis putusan sela yang berhubungan dengan adanya incident, yang diartikan dalam Rv. sebagai peristiwa atau kejadian yang menunda jalannya proses pemeriksaan perkara. ${ }^{34}$ Putusan insidentil belum berhubungan dengan pokok perkara, seperti misalnya putusan yang membolehkan seseorang ikut serta dalam perkara (Vrijwaring yang diatur dalam Pasal 70 Rv. - Pasal 76 Rv., Voeging dan Tussenkomst yang diatur dalam Pasal 279 Rv. - Pasal 282 Rv.)

\section{d. Putusan Provisioneel}

Putusan provisioneel adalah putusan yang dijatuhkan karena kebutuhan mendasar dari salah satu pihak berperkara. Putusan ini bersifat sementara dan diatur dalam Pasal 180 H.I.R dan Pasal $191 \mathrm{Rbg}$. Selain dasar tersebut, ada juga yurisprudensi Mahkamah Agung No. 1070 K/Sip/1972 tanggal 7 Mei 1972, yang pada pokoknya tuntutan provisooneel hanyalah untuk memperoleh tindakan-tindakan sementara selama proses peradilan berjalan dan terhadap tuntutan provisioneel yang mengenai pokok perkara tidak dapat diterima. Putusan provisioneel berisi tindakan sementara menunggu sampai putusan akhir mengenai pokok perkara dijatuhkan. ${ }^{35}$

Dalam beberapa literatur ada perbedaan pendapat mengenai sifat dari putusan ini. Muhammad Nasir berpendapat bahwa sifat dari putusan ini adalah berhubungan dan mempengaruhi pokok perkara. ${ }^{36}$ Hampir serupa diungkapkan oleh Lilik Mulyadi bahwa putusan Provisionil adalah putusan yang menetapkan suatu tindakan sementara bagi kepentingan salah satu pihak berperkara. Misalnya, dalam perkara perceraian yang sedang diadili oleh Pengadilan Negeri, baik sebagai penggugat maupun sebagai tergugat, isteri mohon izin kepada hakim agar boleh meninggalkan rumah suaminya selama

33 M. Yahya Harahap, Hukum Acara Perdata Tentang Gugatan, Persidangan, Penyitaan, Pembuktian, dan Putusan Pengadilan, cet. III, (Jakarta: Sinar Grafika, 2005), hlm. 897.

34 Lilik Mulyadi, Hukum Acara Perdata: Menurut Teori \& Praktek Peradilan Indonesia, (Jakarta: Djambatan, 1999), hlm. 212-213.

${ }^{35}$ Ibid.

${ }^{36}$ Muhammad Nasir, Hukum Acara Perdata, cet. II, (Jakarta: Djambatan, 2005), hal. 195. 
berlangsung persidangan dan hakim dalam putusan provisionil dapat menunjuk rumah dimana isteri itu harus tinggal berdasarkan Pasal 212 KUHPerdata.

Sementara menurut Yahya Harahap putusan ini tidak mengenai pokok perkara, tetapi hanya terbatas mengenai tindakan sementara, misalnya melarang untuk meneruskan pembangunan di atas tanah terperkara dengan ancaman hukuman membayar uang paksa. Hal ini sebagaimana yang ditegaskan dalam salah satu putusan Mahkamah Agung yang menyatakan bahwa gugatan provisioneel seharusnya bertujuan agar ada tindakan sementara dari hakim mengenai hal yang tidak termasuk pokok perkara, sehingga gugatan atau permohonan provisioneel mengenai pokok perkara harus ditolak. ${ }^{37}$ Contoh lainnya, seperti dalam perkara jual-beli gula pasir, oleh karena obyek perkara merupakan barang bergerak yang nilai ekonominya cenderung naik turun, maka pihak penggugat/tergugat dapat memohon putusan provisioneel untuk diadakan lelang atas gula tersebut dan uang hasil lelang tersebut dititipkan di pengadilan. Akan tetapi perlu diperhatikan dalam putusan Mahkamah Agung No. 1400 K/Sip/1974 tanggal 18 November 1975, yang pada pokoknya menyatakan bahwa pemeriksaan tuntutan provisioneel dan dalam pemeriksaan pokok perkara tidak mengakibatkan batalnya seluruh putusan, karena tuntutan provisioneel sifatnya mempermudah pemeriksaan dalam pemutusan dalam pokok perkara.

Putusan akhir adalah putusan yang mengakhiri suatu sengketa atau perkara dalam suatu tingkatan peradilan tertentu. Putusan akhir ada yang bersifat menghukum (condemnatoir), ada yang bersifat menciptakan (constitutief), dan ada yang bersifat menerangkan atau menyatakan (declaratoir). Pembahasan mengenai putusan condemnatoir, putusan constitutief, dan putusan declaratoir akan dibahas dalam sub bab tersendiri dalam bab ini. Selain ketiga putusan berdasarkan sifat amar putusan di atas, terdapat putusan verstek, putusan contradictoir, dan putusan gugatan gugur yang akan dibahas sebagai berikut.

a. Putusan verstek;

Putusan ini dijatuhkan karena tergugat dan/atau wakilnya yang sah tidak hadir dalam persidangan yang telah ditentukan, meskipun telah dipanggil secara sah dan patut. Putusan ini diatur dalam Pasal 125 ayat (1) H.I.R., Pasal 149 Rbg., dan Pasal 78 Rv. Menurut Pasal 125 H.I.R., syarat-syarat yang harus dipenuhi agar dapat dijatuhkannya putusan verstek adalah:

1. Tergugat telah dipanggil secara sah dan patut;

2. Tergugat dan/atau wakilnya tidak hadir tanpa alasan yang sah;

3. Tergugat tidak mengajukan eksepsi (perlawanan); dan

4. Tuntutan penggugat tidak melawan hak si tergugat dan beralasan.

37 M. Yahya Harahap, Hukum Acara Perdata Tentang Gugatan, Persidangan, Penyitaan, Pembuktian, dan Putusan Pengadilan, cet. III, (Jakarta: Sinar Grafika, 2005), hlm. 897. 
Proses pembuktian tetap dilakukan walaupun tergugat tidak hadir, karena penggugat tetap harus membuktikan dalilnya yang dimuat dalam gugatan tanpa terkecuali. Hal tersebut sebagaimana isi Pasal 163 H.I.R. Oleh karena tergugat tidak hadir dalam persidangan, padahal ia sudah dipanggil secara sah dan patut, tergugat dianggap mengakui dalil gugatan penggugat secara murni dan bulat berdasarkan Pasal 174 H.I.R. dan Pasal 1925 KUHPerdata, ${ }^{38}$ dan atas dasar anggapan pengakuan tersebut, maka gugatan penggugat dikabulkan, kecuali jika gugatan itu tanpa hak atau tanpa dasar hukum.

Sementara bagi tergugat, upaya hukum yang dapat ditempuh untuk menghadapi putusan verstek adalah mengajukan perlawanan atau verzet ke pengadilan negeri yang menjatuhkan putusan verstek. Perlawanan terhadap putusan verstek tidak boleh diperiksa dan diputus sebagai perkara baru, sebagaimana tercantum dalam putusan Mahkamah Agung No. 307 K/Sip/1975 tanggal 12 September 1976. Dengan kata lain, perlawanan masih dalam satu register perkara pada putusan verstek. Adapun tenggang waktu dalam mengajukan perlawanan ini selambat-lambatnya 14 (empat) belas hari sejak putusan verstek diberitahukan kepada tergugat secara sah, sebagaimana diatur dalam Pasal 129 H.I.R. dan Pasal 152 ayat (1) Rbg. Apabila perlawanan diajukan terlambat, maka perlawanan harus dinyatakan tidak dapat diterima, bukan ditolak, sebagaimana tercantum dalam putusan Mahkamah Agung No. 290 K/Sip/1973 tanggal 13 Agustus 1974. Selain itu, perlawanan (verzet) terhadap putusan verstek hanya dapat diajukan oleh pihak-pihak dalam perkara, tidak boleh pihak ketiga, sebagaimana tercantum dalam putusan Mahkamah Agung No. 524 K/Sip/1975 tanggal 7 Februari 1980.

b. Putusan contradictoir.

Putusan ini merupakan putusan yang dijatuhkan oleh hakim dalam hal tergugat pernah datang menghadap di persidangan walau sekalipun ia tidak memberi perlawanan/pengakuan. ${ }^{39}$ Dengan kata lain putusan ini adalah putusan yang dijatuhkan karena kehadiran para pihak yang hadir. Misalnya: A sebagai Penggugat menggugat si $\mathrm{B}$ karena masalah piutang di Pengadilan Negeri. Setelah dipanggil dengan sah dan patut, si B (tergugat) pada persidangan datang dan untuk selanjutnya tidak pernah datang lagi hingga perkara selesai diperiksa. Terhadap perkara tersebut dimana $\mathrm{B}$ pernah datang menghadap diputus dengan putusan contradictoir. Contoh lain adalah A menggugat kepada B, C, D, dan E. Dalam persidangan yang hadir ternyata hanya E saja, sedangkan B, C, D tidak pernah hadir sekalipun di persidangan. Terhadap para tergugat tersebut $(\mathrm{B}, \mathrm{C}, \mathrm{D}$, dan $\mathrm{E})$, maka perkara diputus dengan putusan contradictoir.

c. Putusan gugatan gugur;

\footnotetext{
${ }^{38}$ Ibid., hlm. 874. Menurut Yahya Harahap, putusan verstek adalah hukuman yang diberikan oleh undang-undang bagi tergugat yang tidak datang/hadirnya ke persidangan.

39 Lilik Mulyadi, Hukum Acara Perdata: Menurut Teori \& Praktek Peradilan Indonesia, (Jakarta: Djambatan, 1999), hlm. 213.
} 
Apabila penggugat tidak datang pada hari sidang yang telah ditentukan, atau tidak menghadirkan wakilnya padahal telah dipanggil secara sah dan patut, maka dalam hal ini hakim dapat dan berwenang untuk menjatuhkan putusan menggugurkan gugatan penggugat, dan bersamaan dengan itu penggugat dihukum membayar biaya perkara, sebagaimana yang diatur dalam Pasal 124 H.I.R. dan Pasal 77 Rv. Berdasarkan Pasal tersebut, maka alasan digugurkannya gugatan penggugat oleh pengadilan karena:

- penggugat dan/atau kuasanya tidak datang pada hari sidang pertama yang telah ditentukan tanpa alasan yang sah;

- penggugat telah dipanggil secara sah dan patut;

Pengguguran gugatan dilakukan oleh Majelis Hakim yang berwenang secara ex-officio apabila alasan yang tersebut dalam Pasal 124 H.I.R. telah terpenuhi. Dengan kata lain, bahwa kewenangan pengguguran gugatan itu dapat dilakukan oleh hakim meskipun tidak ada permintaan dari pihak tergugat. ${ }^{40}$ Oleh karena tidak hadirnya penggugat dalam persidangan mengakibatkan dalildalil yang diajukan dalam gugatan tidak dapat dibuktikan dan proses pembuktian sebagaimana diatur dalam Pasal 163 H.I.R. tidak ada. Sementara akibat hukum yang timbul dari putusan adalah pihak tergugat dilepaskan dari tuntutan penggugat sebagaimana yang dikemukakan dalam gugatan penggugat, dan satu-satunya upaya yang dapat ditempuh pengugat untuk menghadapi putusan ini hanyalah mengajukan gugatan baru.

Selain putusan sela dan putusan akhir, ada juga yang dinamakan putusan pengadilan yang telah berkekuatan hukum tetap (in kracht van gewijsde). Pada praktiknya putusan yang telah berkekuatan hukum tetap dibedakan antara putusan pengadilan dalam bidang pidana dan putusan pengadilan dalam bidang perdata, karena berkaitan dengan eksekusi atau pelaksanaan putusannya yang berbeda. Putusan pengadilan yang telah berkekuatan hukum tetap atau in kracht van gewijsde baik dibidang pidana maupun bidang perdata adalah suatu putusan pengadilan yang tidak lagi terbuka kemungkinan untuk dibatalkan dengan upaya hukum verzet, banding atau kasasi. ${ }^{41}$ Adanya upaya hukum luar biasa yang disebut derden verzet atau Permohonan Peninjauan Kembali adalah ditujukan kepada suatu Putusan Pengadilan yang sebenarnya telah mempunyai kekuatan hukum yang tetap (in kracht van gewijsde). Secara khusus dalam perkara pidana, putusan pengadilan yang telah berkekuatan hukum tetap dapat dilihat dalam Undang-Undang Nomor 5 Tahun 2010 tentang Perubahan atas Undang-Undang Nomor 22 Tahun 2002 tentang Grasi. Pada penjelasan Pasal 2 ayat (1) Undang-Undang Nomor 5 Tahun 2010 tentang Perubahan atas Undang-Undang Nomor 22 Tahun 2002 tentang Grasi menyebutkan bahwa

40 Ivan Ari, "Gugurnya Suatu Gugatan,"
<http://www.hukumacaraperdata.com/gugurnya-suatu-gugatan/>, diakses pada 3 Juni 2016.

41 "Pengertian Eksekusi Definisi Sumber Hukum Perdata dan Putusan Pengadilan yang Berkekuatan Hukum Tetap," $\quad<$ http://www.landasanteori.com/2015/09/pengertianeksekusi-definisi-sumber.html>, diakses pada 31 Mei 2016. 
yang dimaksud dengan putusan pengadilan yang telah memperoleh kekuatan hukum tetap adalah:

1. Putusan pengadilan tingkat pertama yang tidak diajukan banding setelah waktu tujuh hari sesudah putusan dijatuhkan atau setelah putusan diberitahukan kepada terdakwa yang tidak hadir, sebagaimana diatur dalam Pasal 233 ayat (2) jo. Pasal 234 ayat (1) KUHAP., kecuali untuk putusan bebas (vrijspraak), putusan lepas dari segala tuntutan hukum (onslag van rechts vervolging), dan putusan pemeriksaan acara cepat karena putusan-putusan tersebut tidak dapat diajukan banding;

2. Putusan pengadilan tingkat banding yang tidak diajukan kasasi dalam waktu empat belas hari sesudah putusan pengadilan yang dimintakan kasasi itu diberitahukan kepada terdakwa (Pasal 245 ayat (1) jo. Pasal 246 ayat (1) K.U.H.A.P.).; atau

3. Putusan kasasi.

\section{Sifat Amar Putusan Pengadilan}

Ditinjau dari sifatnya, maka putusan hakim ini dapat dibedakan menjadi 3 (tiga) macam, yaitu:

1) Putusan Declaratoir

Putusan declaratoir adalah putusan yang dijatuhkan oleh hakim dengan amar yang menyatakan atau menegaskan tentang suatu keadaan atau kedudukan yang sah menurut hukum semata-mata, ${ }^{42}$ misalnya tentang kedudukan sebagai anak sah, kedudukan sebagai ahli waris, atau tentang pengangkatan anak. Putusan ini dinyatakan hukum tertentu yang dituntut atau dimohon oleh penggugat atau pemohon ada atau tidak ada, tanpa mengakui adanya hak atas suatu prestasi tertentu. Putusan declaratoir murni tidak mempunyai atau memerlukan upaya pemaksa karena sudah mempunyai akibat hukum tanpa bantuan dari pihak lawan yang dilakukan untuk melaksanakannya, sehingga hanya mempunyai kekuatan mengikat saja. ${ }^{43}$

Tidak ada putusan yang tidak bersifat atau mengandung amar declaratoir. Putusan terhadap sengketa perkara perbuatan melawan hukum berdasarkan Pasal 1365 KUHPerdata, jika gugatan dikabulkan, putusan didahului dengan amar declaratoir berupa pernyataan, bahwa tergugat terbukti bersalah melakukan perbuatan melawan hukum. Bahkan putusan yang menolak gugatan pun, mengandung pernyataan, bahwa gugatan penggugat ditolak. Penolakan itu sendiri, tiada lain penegasan bahwa penggugat tidak berhak atau tidak memiliki status atas masalah yang disengketakan. ${ }^{44}$

2) Putusan Constitutief

\footnotetext{
${ }^{42}$ Ibid., hal. 876.

${ }^{43}$ Mertokusumo, Mengenal Hukum Suatu Pengantar, cet. 4, (Yogyakarta: Liberty, 2008), hlm 175.

44 M. Yahya Harahap, Hukum Acara Perdata Tentang Gugatan, Persidangan, Penyitaan, Pembuktian, dan Putusan Pengadilan, cet. III, (Jakarta: Sinar Grafika, 2005), hlm. 897.
} 
Putusan constitutief adalah putusan yang dijatuhkan oleh hakim yang amarnya menciptakan suatu keadaan hukum yang baru, ${ }^{45}$ baik yang bersifat meniadakan suatu keadaan hukum maupun yang menimbulkan keadaan hukum baru. ${ }^{46}$ Misalnya putusan perceraian, merupakan putusan yang meniadakan keadaan hukum yakni tidak ada lagi ikatan hukum antara suami dan istri sehingga putusan itu meniadakan hubungan perkawinan yang ada, dan bersamaan dengan itu timbul keadaan hukum yang baru kepada suami dan istri, yaitu sebagai janda dan duda. ${ }^{47}$ Tiadanya hubungan perkawinan menyebabkan hilang atau tidak adanya hak dan kewajiban bagi suami atau istri, sebagaimana diatur dalam Pasal 41 Undang-Undang Nomor 1 Tahun 1974 tentang Perkawinan. Dengan kata lain hubungan hukum yang hilang adalah hubungan hukum antara suami dan istri bukan antara orangtua dan anak.

Sebenarnya hampir tidak ada batas antara putusan declaratoir dengan putusan contitutief. Misalnya putusan contitutief yang menyatakan perjanjian batal, pada dasarnya amar yang berisi pembatalan perjanjian adalah bersifat declaratief yakni yang berisi penegasan hubungan hukum atau keadaan yang mengikat para pihak dalam perjanjian itu tidak sah oleh karena itu perjanjian dinyatakan batal. ${ }^{48}$

Seperti halnya putusan declaratoir, putusan contitutief juga tidak menetapkan adanya hak, sehingga tidak memerlukan upaya pemaksa karena akibat hukum atau pelaksanaannya tidak tergantung pada kemauan/kesukarelaan dari pihak lawan yang dikalahkan. ${ }^{49}$

\section{3) Putusan Condemnatoir}

Putusan condemnatoir adalah putusan yang dijatuhkan oleh hakim dengan amar yang bersifat menghukum. Bentuk hukuman dalam perkara perdata berbeda dengan hukuman dalam perkara pidana. Dalam perkara perdata, bentuk hukumannya berupa kewajiban untuk melaksanakan atau memenuhi hak si pihak yang dilanggar, yang dibebankan kepada pihak yang terhukum. ${ }^{50}$ Sedangkan dalam perkara pidana, bentuk hukuman yang diberikan adalah hukuman/sanksi pidana yang secara umum dapat berupa pidana badan atau pada pidana khusus yaitu yang diwajibkan untuk membayar sejumlah uang.

Berbeda dengan dua sifat putusan sebelumnya, yaitu putusan declaratoir dengan putusan constitutief, putusan condemnatoir mengakui atau menetapkan adanya hak, sehingga putusan ini memerlukan upaya pemaksa karena

${ }^{45}$ Riduan Syahrani, Hukum Acara Perdata di Lingkungan Peradilan Umum, cet. I, (Jakarta: Pustaka Kartini, 1998), hlm. 88.

46 M. Yahya Harahap, Hukum Acara Perdata Tentang Gugatan, Persidangan, Penyitaan, Pembuktian, dan Putusan Pengadilan, cet. III, (Jakarta: Sinar Grafika, 2005), hlm. 897.

${ }^{47}$ Ibid., hlm. 876-877.

${ }^{48}$ Ibid.

${ }^{49}$ Mertokusumo, Mengenal Hukum Suatu Pengantar, cet. 4, (Yogyakarta: Liberty, 2008), hlm. 174.

${ }^{50}$ Muhammad Nasir, Hukum Acara Perdata, cet. II, (Jakarta: Djambatan, 2005), hlm. 187. 
pelaksanaannya tergantung pada kemauan/kesukarelaan dari pihak yang terhukum.

Sementara menurut Yahya Harahap putusan yang bersifat condemnatoir merupakan bagian yang tidak terpisahkan dari amar declaratoir atau constitutief. Yahya Harahap dalam bukunya yang berjudul hukum acara perdata menyatakan bahwa amar condemnatoir adalah accessoir dari amar declaratoir atau constitutief, karena amar tersebut tidak dapat berdiri sendiri tanpa didahului amar declaratoir atau constitutief yang menyatakan bagaimana keadaan atau hubungan hukum di antara para pihak. Amar putusan yang bersifat declaratoir merupakan conditio sine quo non ${ }^{51}$ atau merupakan syarat mutlak untuk menjatuhkan putusan condemnatoir. Penempatan amar declaratoir atau constitutief dalam putusan harus ditempatkan mendahului amar condemnatoir. Amar putusan yang bersifat declaratief atau constitutief dapat berdiri sendiri tanpa amar putusan condemnatoir. Putusan yang hanya berisi amar declaratoir atau constitutief dirasakan tidak besar manfaatnya atau tidak efektif dalam menyelesaikan suatu sengketa, karena putusan yang demikian tidak dapat dipaksakan melalui executie apabila pihak yang terhukum tidak mau melaksanakan secara sukarela, sehingga putusan yang dijatuhkan tidak tuntas dalam menyelesaikan sengketa. ${ }^{52}$

\section{Kekuatan Putusan Pengadilan}

Tujuan diadakannya suatu proses persidangan di muka pengadilan adalah untuk memperoleh putusan hakim. ${ }^{53}$ Untuk dapat memutus suatu perkara, hakim harus terlebih dahulu mengetahui secara obyektif tentang duduknya perkara sebenarnya sebagai dasar putusan. Hakim dianggap tahu akan hukumnya (ius curia novit), karena soal menemukan hukum adalah urusan hakim dan bukan urusan kedua belah pihak (Penggugat dan Tergugat). ${ }^{54}$ Hakim dalam mempertimbangkan putusan wajib karena jabatannya melengkapi alasan-alasan hukum yang tidak dikemukakan oleh para pihak, hal tersebut sesuai dengan aturan dalam Pasal 178 ayat (1) Herzien Inlandsch Reglement (H.I.R). Prof. Sudikno Mertokusumo, S.H. memberikan definisi bahwa putusan hakim adalah suatu pernyataan yang oleh hakim, sebagai pejabat yang diberi wewenang itu, diucapkan di persidangan dan bertujuan mengakhiri atau menyelesaikan suatu perkara atau suatu sengketa antara para pihak. ${ }^{55}$

Beberapa ahli hukum lainnya, seperti Lilik Mulyadi dan Riduan Syahrani, S.H. memberikan definisi putusan yang hanya terbatas dalam ruang lingkup hukum acara perdata. Lilik Mulyadi memberikan definisi putusan

\footnotetext{
${ }^{51}$ Subekti dan Tjitrosoedibio, op. cit., hlm. 32 atau Pandu, op. cit., hlm. 42. conditio sine quo non adalah syarat mutlak, suatu syarat yang mana tanpa itu perjanjian tidak berlaku.

52 Harahap, Hukum Acara Perdata Tentang Gugatan, Persidangan, Penyitaan, Pembuktian, dan Putusan Pengadilan, cet. III, (Jakarta: Sinar Grafika, 2005), hlm. 877-878.

${ }^{53}$ M. Nur Rasaid, Hukum Acara Perdata, cet. III, (Jakarta: Sinar Grafika Offset, 2003), hlm. 48.

${ }^{54}$ Sudikno Mertokusumo, Hukum Acara Perdata Indonesia, cet. III, (Yogyakarta: Liberty, 1981), hlm. 152.

${ }_{55}$ Mertokusumo, Mengenal Hukum Suatu Pengantar, cet. 4, (Yogyakarta: Liberty, 2008), hlm. 158.
} 
hakim yang ditinjau dari visi praktik dan teoritis, yaitu putusan yang diucapkan oleh hakim karena jabatannya dalam persidangan perkara perdata yang terbuka untuk umum setelah melalui proses dan prosedural hukum acara perdata pada umumnya dibuat dalam bentuk tertulis dengan tujuan menyelesaikan atau mengakhiri suatu perkara. ${ }^{56}$ Sedangkan Riduan Syahrani, S.H. lebih suka menggunakan istilah putusan pengadilan sebagai pernyataan yang diucapkan hakim yang diucapkan pada sidang pengadilan yang terbuka untuk umum untuk menyelesaikan atau mengakhiri perkara perdata. ${ }^{57}$ Adapun pengertian lainnya, putusan pengadilan merupakan hasil suatu rangkaian (proses) tindakan dan perlakuan hakim selama mengadili dan memperlakukan para pihak yang berperkara berdasarkan peraturan perundang-undangan, yang dapat dirasakan pencari keadilan. ${ }^{58}$ Beberapa ahli hukum lainnya, seperti Lilik Mulyadi dan Riduan Syahrani, S.H. memberikan definisi putusan yang hanya terbatas dalam ruang lingkup hukum acara perdata. Lilik Mulyadi memberikan definisi putusan hakim yang ditinjau dari visi praktik dan teoritis, yaitu putusan yang diucapkan oleh hakim karena jabatannya dalam persidangan perkara perdata yang terbuka untuk umum setelah melalui proses dan prosedural hukum acara perdata pada umumnya dibuat dalam bentuk tertulis dengan tujuan menyelesaikan atau mengakhiri suatu perkara. ${ }^{59}$ Sedangkan Riduan Syahrani, S.H. lebih suka menggunakan istilah putusan pengadilan sebagai pernyataan yang diucapkan hakim yang diucapkan pada sidang pengadilan yang terbuka untuk umum untuk menyelesaikan atau mengakhiri perkara perdata. ${ }^{60}$ Adapun pengertian lainnya, putusan pengadilan merupakan hasil suatu rangkaian (proses) tindakan dan perlakuan hakim selama mengadili dan memperlakukan para pihak yang berperkara berdasarkan peraturan perundang-undangan, yang dapat dirasakan pencari keadilan. ${ }^{61}$

Kekuatan putusan pengadilan sebenarnya sama sekali tidak dimuat dalam H.I.R. maupun R.Bg., kecuali Pasal 180 H.I.R. dan Pasal 191 R.Bg. yang hanya menyebutkan adanya suatu putusan yang telah mempunyai kekuatan hukum tetap. Untuk itu, dengan adanya putusan hakim yang telah mempunyai kekuatan hukum tetap, maka sudah tentu ada juga putusan hakim yang belum mempunyai kekuatan hukum tetap.

Putusan hakim yang belum mempunyai kekuatan hukum tetap adalah putusan yang menurut ketentuan undang-undang masih terbuka kesempatan untuk menggunakan upaya hukum biasa melawan putusan itu, misalnya

${ }^{56}$ Ibid., hlm. 204.

57 Riduan Syahrani, Hukum Acara Perdata di Lingkungan Peradilan Umum, cet. I, (Jakarta: Pustaka Kartini, 1998), hlm. 88.

58 Sri Laksmi Anindita, "Keyakinan Hakim Dalam Menjatuhkan Putusan Perkara Pidana," dalam Praperadilan dan Perkembangannya Dalam Hukum Acara Pidana Indonesia, ed. Disriani Latifah Soroinda, (Depok: Badan Penerbit FHUI, 2016), hlm. 140.

${ }^{59}$ Ibid., hlm. 204.

${ }^{60}$ Riduan Syahrani, Hukum Acara Perdata di Lingkungan Peradilan Umum, cet. I, (Jakarta: Pustaka Kartini, 1998), hlm. 88.

${ }^{61}$ Sri Laksmi Anindita, "Keyakinan Hakim Dalam Menjatuhkan Putusan Perkara Pidana," dalam Praperadilan dan Perkembangannya Dalam Hukum Acara Pidana Indonesia, ed. Disriani Latifah Soroinda, (Depok: Badan Penerbit FHUI, 2016), hlm. 140. 
perlawanan (verzet), banding, atau kasasi. Sedangkan putusan yang telah mempunyai kekuatan hukum tetap adalah putusan yang menurut ketentuan undang-undang tidak ada kesempatan lagi untuk menggunakan upaya hukum biasa (perlawanan (verzet), banding, atau kasasi) melawan putusan itu. Jadi putusan itu tidak dapat lagi diganggu gugat. ${ }^{62}$

Menurut doktrin, dalam putusan yang telah mempunyai kekuatan hukum tetap terdapat 3 (tiga) macam kekuatan untuk dapat dilaksanakan. ${ }^{63}$

1) Kekuatan Mengikat

Apabila pihak yang bersengketa tidak dapat menyelesaikan sengketa diantara mereka secara damai, dan kemudian menyerahkan dan mempercayakan sengketanya kepada pengadilan atau hakim untuk diperiksa dan diadili, maka hal ini mengandung arti bahwa pihak-pihak yang bersengketa akan tunduk dan patuh pada putusan yang dijatuhkan, sehingga putusan itu mempunyai kekuatan mengikat terhadap pihak-pihak yang bersengketa.

2) Kekuatan Pembuktian

Dituangkannya putusan dalam bentuk tertulis, yang merupakan akta otentik, tidak lain bertujuan untuk dapat digunakan sebagai alat bukti bagi para pihak, yang mungkin diperlukannya untuk mengajukan upaya hukum. Karena meskipun putusan hakim atau putusan pengadilan tidak mempunyai kekuatan mengikat terhadap pihak ketiga, namun mempunyai kekuatan pembuktian terhadap pihak ketiga. ${ }^{64}$

3) Kekuatan Executorial

Kekuatan executorial dalam putusan hakim atau putusan pengadilan adalah kekuatan untuk dilaksanakan secara paksa oleh alat-alat negara terhadap pihak-pihak yang tidak melaksanakan putusan tersebut secara sukarela. ${ }^{65}$ Sebenarnya yang memberi kekuatan executorial kepada putusan hakim atau putusan pengadilan adalah kata-kata, "Demi Keadilan Berdasarkan Ketuhanan Yang Maha Esa” yang ada pada setiap putusan. Tidak semua putusan dapat dilaksanakan secara paksa oleh pengadilan. Hanya putusan condemnatoir sajalah yang dapat dilaksanakan secara paksa oleh pengadilan, sementara putusan declatoir dan constitutief tidak.

\section{Eksekusi Uang Pengganti Berdasarkan UU No. 3 Tahun 1971 tentang Pemberantasan Tindak Pidana Korupsi}

Eksekusi uang pengganti yang dijatuhkan berdasarkan UU Tindak pidana korupsi tahun 1971, setelah putusan berkekuatan hukum tetap menyatakan terdapat kerugian negara yang harus dibayar dengan cara dijatuhkannya hukuman uang pengganti kepada terdakwa, Jaksa Penuntut Umum langsung mengeksekusi harta sitaan yang telah dilakukan Jaksa yang diduga merupakan hasil tindak pidana korupsi dengan cara melakukan lelang terhadap harta sitaan

${ }^{62}$ Muhammad, Hukum Acara Perdata, cet. II, (Jakarta: Djambatan, 2005), hlm. 174175.

63 Supomo, Hukum Atjara Perdata Pengadilan Negeri, (Jakarta: Fasco Djakarta, 1958), hlm. 136.

${ }^{64}$ Ibid., hlm. 155.

${ }^{65}$ Ibid. 
melalui Kantor Lelang Negara. Oleh karena terdapat ketidakjelasan untuk eksekusi uang pengganti, yaitu pada penjelasan Pasal 34 huruf c, apabila terdakwa tidak memenuhi hukuman pengganti, maka berlaku ketentuan mengenai pelaksanaan pembayaran hukum denda. Sehingga menimbulkan keraguan apakah eksekusi uang pengganti dapat diganti dengan hukuman kurungan seperti hukuman/sanksi pidana denda. Pada tahun 1988, Mahkamah Agung mengeluarkan S.E.M.A Nomor 4 Tahun 1988 tentang Eksekusi Terhadap Hukuman Pembayaran Uang Pengganti yang pada intinya Mahkamah Agung menjelaskan bahwa:

1. Terhadap penjatuhan pidana pembayaran uang pengganti tidak dapat ditetapkan hukuman kurungan sebagai ganti apabila uang pengganti tersebut dibayar oleh terpidana;

2. Eksekusi atas pidana pembayaran uang pengganti apabila akan dilaksanakan oleh Jaksa tidak lagi memerlukan campur tangan pihak pengadilan misalnya dalam bentuk izin penyitaan yang dituangkan dalam Penetapan dan lain-lain. Hal ini di dasarkan pada pendapat bahwa penyitaan terhadap barang-barang milik terpidana adalah masih merupakan pelaksanaan dari apa yang sudah diputuskan oleh Hakim;

3. Baru apabila seandainya dalam pelaksanaan kali ini jumlah barangbarang yang dimiliki oleh terpidana sudah tidak mencukupi lagi, sisanya apabila masih akan ditagihkan oleh kejaksaan pada lain kesempatan harus diajukan melalui gugatan perdata di pengadilan. ${ }^{66}$

Dengan demikian, apabila harta sitaan yang ada pada Jaksa ternyata tidak dapat memenuhi kerugian negara yang ada pada hukuman/sanksi uang pengganti, maka berdasarkan S.E.M.A Nomor 4 Tahun 1988 tentang Eksekusi Terhadap Hukuman Pembayaran Uang Pengganti, Jaksa dapat mengajukan gugatan perdata kepada terdakwa untuk pemenuhan hukuman uang pengganti bila diketahui ada aset milik terdakwa yang dapat dituntut. Pada Peraturan Jaksa Agung RI No. B-020/A/J.A/04/2009 tentang Tata Cara Penyelesaian Denda dan Uang Pengganti dalam Perkara Tindak Pidana Korupsi, terhadap penyelesaian uang pengganti yang diatur dalam UU Tindak Pidana Korupsi tahun 1971 menyatakan bahwa jika ditemukan harta benda milik terpidana segera disampaikan ke bidang DATUN ${ }^{67}$ untuk ditindaklanjuti, demikian juga apabila tidak ditemukan harta benda milik terpidana atau terpidana dalam keadaan tidak mampu, sesuai dengan surat keterangan yang ditandatangani oleh lurah atau kepala desa tempat tinggal terpidana. Selanjutnya dalam peraturan kejaksaan tersebut diatur bahwa apabila uang pengganti tidak

\footnotetext{
${ }^{66}$ Indonesia, Mahkamah Agung, Surat Edaran Mahkamah Agung tentang Eksekusi Terhadap Hukuman Pembayaran Uang Pengganti, SEMA No. 4 Tahun 1988.

${ }^{67}$ DATUN merupakan bidang Perdata dan Tata Usaha Negara yang dalam hal ini bertugas untuk pelaksanaan gugatan uang pengganti atas putusan pengadilan, gugatan ganti kerugian dan tindakan hukum lain terhadap perbuatan yang melawan hukum yang merugikan keuangan negara.
} 
dibayar, maka pihak yang dirugikan baik Instansi Pemerintah, BUMN, BUMD maupun Badan Hukum lain yang mengelola keuangan negara masih berhak untuk menuntut ganti rugi kepada terpidana apabila dikemuadian hari ternyata memiliki harta kekayaan dengan dasar Pasal 1365 KUHPerdata yang dalam pelaksanaannya dapat memberi surat kuasa khusus kepada Kejakasaan selaku Jaksa Pengacara Negara. Sehingga dengan kata lain, maksud dari peraturan kejaksaan di atas adalah apabila dikemudian hari ditemukan harta benda baik bergerak maupun tidak bergerak milik terpidana, sedangkan ia belum sama sekali melaksanakan pidana uang pengganti atau belum melaksanakan pemenuhan hukuman/sanksi pidana uang pengganti, maka Jaksa selaku Jaksa Pengacara Negara dapat menuntut ganti rugi secara perdata berdasarkan Pasal 1365 KUHPerdata.

Selain peraturan Jaksa Agung di atas, ada juga Peraturan Jaksa Agung RI No. PER-020/A/JA/07/2014 tentang Petunjuk Pelaksanaan Penyelesaian Uang Pengganti Yang Diputus Pengadilan Berdasarkan UU Nomor 3 Tahun 1971. Dalam peraturan jaksa ini, terdapat dua cara penyelesaian uang pengganti, yaitu penyelesaian secara non litigasi dan penyelesaian secara litigasi. Penyelesaian secara non litigasi dilakukan dengan cara negosiasi atau musyawarah dengan terpidana atau ahli warisnya. Ruang lingkup negosiasi tersebut hanya terbatas pada sistem pembayaran secara tunai atau angsuran, yang harus dibayar sesuai putusan pengadilan yang berkekuatan hukum tetap. Adapun jangka waktu dengan cara non litigasi adalah 4 (empat) bulan, dan apabila ternyata terpidana tidak dapat memenuhi kewajibannya, maka ditindaklanjuti dengan gugatan perdata yang merupakan penyelesaian secara litigasi. Sebelum mengajukan gugatan perdata, Jaksa melakukan penelusuran secara maksimal terhadap harta benda milik terpidana yang kemudian dibuktikan dengan Berita Acara Penelusuran Aset. Pada gugatan perdata tersebut kemudian disertakan pula permohonan sita jaminan terhadap harta benda milik tergugat/semula terpidana.

\section{Pembahasan}

\section{Unsur Eksekusi}

Suatu putusan yang telah berkekuatan hukum tetap mempunyai kekuatan eksekutorial, baik pihak yang kalah ingin melaksanakan secara sukarela, maupun tidak dilaksanakan secara sukarela. Hukuman/sanksi pidana uang pengganti yang tidak dilaksanakan oleh tergugat dalam ketiga putusan ini, terdapat pada amar putusan akhir yang bersifat condemnatoir. Dengan kata lain hakim menghukum terpidana (dalam hal ini tergugat) dengan hukuman/sanksi pidana. Jaksa selaku eksekutor dalam melaksanakan suatu putusan pengadilan pidana diberi kewenangan berdasarkan Pasal 270 KUHAP. Selain itu, pada Pasal 54 ayat (1) UU No. 48 Tahun 2009 tentang Kekuasaan Kehakiman dan Pasal 30 ayat (1) huruf b UU Nomor 16 Tahun 2004 tentang Kejaksaan Republik Indonesia menyatakan bahwa, pelaksanaan putusan pengadilan dalam perkara pidana dilakukan oleh jaksa, sehingga diberikan wewenang untuk melaksanakan putusan hakim yang berkekuatan hukum tetap. Dengan kata lain, melaksanakan putusan pengadilan pidana yang telah memperoleh 
kekuatan hukum tetap merupakan kewajiban hukum Jaksa. Secara umum, unsur eksekusi jika melihat ketentuan pada Pasal 270 KUHAP adalah bahwa putusan pengadilan sudah memiliki kekuatan hukum yang tetap; eksekusi putusan dilaksanakan oleh Jaksa; dan Jaksa melaksanakan eksekusi setelah mendapat salinan putusan yang sudah memiliki kekuatan hukum tetap dari panitera Pengadilan Negeri yang bersangkutan. Berkaitan dengan putusan yang hendak dianalisa, Jaksa yang menerima perintah berwenang untuk melaksanakan putusan pengadilan dengan nomor 73/Pid.B/2002/PN.Ung tanggal 23 Oktober 2002, putusan nomor $718 \mathrm{~K} / \mathrm{Pid} / 1985$ tanggal $25 \mathrm{Juni}$ 1985, dan putusan nomor $107 \mathrm{~K} / \mathrm{Pid} / 1994$ tanggal 29 Mei 1994 yang telah berkekuatan hukum tetap. Adapun dalam eksekusinya kemudian akan dibahas sebagai berikut.

\section{Eksekusi Pidana Pokok}

Berdasarkan Pasal 48 Peraturan Jaksa Agung RI Nomor PER036/A/JA/09/2011 tentang Standar Operasional Penanganan Perkara Tindak Pidana Umum, mengatur bahwa pelaksanaan putusan yang berkekuatan hukum tetap dilaksanakan oleh Jaksa berdasarkan Surat Perintah Kepala Kejaksaan Negeri yang menangani perkara, dimana surat perintah tersebut ditandai dengan berkas P-48. Surat perintah tentang pelaksanaan putusan pengadilan yang berkekuatan hukum tetap dikeluarkan selambat-lambatnya 3 (tiga) hari sejak diterimanya putusan pengadilan tersebut. Pelaksanaan putusan pengadilan dilaksanakan secara tuntas (pidana badan, denda, barang bukti, restitusi, dan biaya perkara) selambat-lambatnya 7 (tujuh) hari sejak diterimanya surat perintah pelaksanaan putusan pengadilan yang kemudian dibuat Berita Acara (BA-17, dahulu BA-8) ${ }^{68}$ oleh Jaksa yang menerima perintah pelaksanaan putusan pengadilan. Dengan demikian, hukuman/sanksi pidana terhadap badan, dalam hal ini hukuman/sanksi pidana penjara dan kurungan, maka setelah putusan sudah mempunyai kekuatan hukum tetap, Jaksa selaku eksekutor yang menerima perintah langsung melaksanakan putusan pengadilan tersebut dengan dibuatkan Berita Acara Pelaksanaan Putusan Pengadilan. Berkaitan dengan putusan pengadilan yang dianalisa, yakni putusan nomor 22/Pdt.G/2010.PN.UNG; putusan nomor 116/Pdt.G/2013/PN.MTR; dan putusan nomor 24/Pdt.G/2013/PN.PRA, masing-masing tergugat sudah melaksanakan pidana pokok yang berdasarkan Berita Acara Pelaksanaan Putusan tanggal 22 Oktober 2002 untuk putusan nomor 22/Pdt.G/2010.PN.UNG, sedangkan untuk dua putusan lainnya Jaksa hanya mendalilkan bahwa tergugat sudah menjalani pidana pokok, tanpa menyebutkan Berita Acara Pelaksanaan Putusan.

\section{Eksekusi Uang Pengganti}

Untuk ketiga putusan pengadilan yang dianalisa, masing-masing putusan menggunakan Undang-Undang No. 3 Tahun 1971 tentang Pemberantasan

${ }^{68}$ Indonesia, Jaksa Agung Republik Indonesia, Surat Edaran Jaksa Agung RI tentang Penyesuaian Kode Formulis Berita Acara Administrasi Perkara Pidana, Surat Edaran Jaksa Agung RI Nomor: SE-009/A/JA/08/2015. 
Tindak Pidana Korupsi. Hal ini dapat diketahui jika melihat amar putusan pengadilan pidana yang dijatuhkan kepada masing-masing tegugat (semula Terpidana). Apabila melihat kasus tindak pidana korupsi yang diadili berdasarkan Undang-Undang Nomor 20 Tahun 2001 tentang Perubahan Atas Undang-Undang Nomor 31 Tahun 1999 tentang Pemberantasan Tindak Pidana Korupsi, diktum terkait pidana uang pengganti tidak hanya menghukum untuk membayar uang pengganti, tetapi hakim memerintahkan jaksa agar harta benda terdakwa dapat disita oleh jaksa dan dilelang untuk menutupi uang pengganti tersebut jika pidana uang pengganti tidak dibayar setelah 1 (satu) bulan putusan berkekuatan hukum tetap, dan dalam hal terdakwa tidak mempunyai harta benda yang mencukupi untuk membayar uang pengganti, maka diganti dengan pidana penjara. ${ }^{69}$

Sedangkan jika melihat amar putusan pengadilan pidana yang mengadili kasus tindak pidana korupsi yang terdapat penjatuhan pidana uang pengganti, maka Majelis Hakim dalam perkara hanya menghukum untuk membayar uang pengganti, seperti putusan yang menjadi bahan analisa. Kemudian ada Peraturan Jaksa Agung RI No. B-020/A/J.A/04/2009 tentang Tata Cara Penyelesaian Denda dan Uang Pengganti dalam Perkara Tindak Pidana Korupsi, terhadap penyelesaian uang pengganti yang diatur dalam UU Tindak Pidana Korupsi tahun 1971 menyatakan bahwa jika ditemukan harta benda milik terpidana segera disampaikan ke bidang DATUN untuk ditindaklanjuti. Maksud ditindaklanjuti dalam hal ini adalah apabila dikemudian hari ditemukan harta benda baik bergerak maupun tidak bergerak milik terpidana, sedangkan ia belum sama sekali melaksanakan pidana uang pengganti atau belum melaksanakan pemenuhan hukuman/sanksi pidana uang pengganti, maka Jaksa selaku Jaksa Pengacara Negara dapat menuntut ganti rugi secara perdata berdasarkan Pasal 1365 KUHPerdata.

Khusus pada putusan nomor 24/Pdt.G/2013/PN.PRA, sebelum mengajukan gugatan perdata kepada penggugat, penggugat telah melakukan upaya untuk bernegosiasi dengan tergugat pada tanggal 9 April 2013 dan 29 April 2013, namun ternyata upaya ini tidak mencapai kesepakatan; akan tetapi hal ini sebenarnya merupakan salah satu bentuk itikad baik yang dilakukan pihak penggugat sebelum menyelesaikan sengketa ke pengadilan. Hal ini juga merupakan salah satu prosedur yang diatur dalam Peraturan Jaksa Agung Republik Indonesia nomor: PER-020/A/JA/07/2014 tentang Petunjuk Pelaksanaan Penyelesaian Uang Pengganti yang Diputus Pengadilan Berdasarkan UU Nomor 3 Tahun 1971 tentang Pemberantasan Tindak Pidana Korupsi, namun dalam perkara ini, Jaksa tidak menggunakan Peraturan Jaksa nomor PER-020/A/JA/07/2014, dikarenakan pengajuan gugatan perdata ini dilakukan pada tanggal 30 April 2013. Pada peraturan jaksa tersebut, sebelum diajukannya gugatan perdata, maka jaksa dapat melakukan musyawarah (negosiasi) untuk memenuhi pelaksanaan hukuman pembayaran uang pengganti.

${ }^{69}$ Lihat amar Putusan Pengadilan Tindak Pidana Korupsi pada Pengadilan Negeri Kendari Nomor 03/Pid.Tipikor/2013/PN.Kdi tanggal 21 Juni 2013; dan amar Putusan Pengadilan Negeri Ambon Nomor 94/Pid.B/2007/PN.AB tanggal 7 April 2008. 
Namun jika melihat keberlakuan Peraturan Jaksa nomor PER020/A/JA/07/2014 dan pengajuan gugatan perdata ini, maka sebenarnya upaya negosiasi jaksa dalam perkara ini adalah atas inisiatif dari Kejaksaan Negeri Praya, dan terhadap hal ini tidak bermasalah. Oleh karena upaya yang dilakukan Penggugat tersebut tidak berhasil, mengakibatkan Penggugat terpaksa untuk mengajukan gugatan perdata ini dengan dasar pemenuhan hukuman pembayaran uang pengganti yang dijatuhkan oleh Tergugat berdasarakan Pasal 27 ayat (1) UUD 1945, Pasal 270 KUHAP, Pasal 1365 KUHPerdata, dan Pasal 30 ayat (1) huruf b Undang-undang Nomor 16 Tahun 2004 Tentang Kejaksaan Republik Indonesia, yang pada pokoknya Jaksa berkewajiban melaksanakan Putusan Pengadilan yang telah berkekuatan hukum tetap.

Jika memperhatikan ketentuan pada peraturan Jaksa Agung Republik Indonesia No. B-020/A/JA/04/2009 tentang Tata Cara Penyelesaian Denda dan Uang Pengganti dalam Perkara Tindak Pidana Korupsi, bahwa sebelum jaksa mengajukan gugatan perdata kepada tergugat untuk menuntut pembayaran uang pengganti jika ditemukan harta benda milik terpidana. Faktanya, pada putusan nomor 22/Pdt.G/2010.PN.UNG; putusan nomor 116/Pdt.G/2013/PN.MTR; dan putusan nomor 24/Pdt.G/2013/PN.PRA, tidak ditemukan harta benda milik terpidana (tergugat dalam perkara ini) yang ingin dituntut sebagai pemenuhan pidana uang pengganti. Harta benda yang ditemukan untuk dituntut dimuka hakim bertujuan sebagai jaminan untuk kepentingan penggugat demi pemenuhan pidana uang pengganti. Terhadap ketiga putusan tersebut, walaupun penggugat berhasil untuk mendapat kepentingannya yang dilindungi oleh suatu putusan perdata, penggugat tidak dapat melakukan eksekusi terhadap harta benda milik tergugat, sehingga dalam hal ini ketiga penggugat dalam putusan yang dianalisa hanya menang di atas kertas. Karena tergugat dalam perkara masih dapat mengelak untuk pemenuhan pidana uang pengganti. Bahkan tuntutan yang terdapat sita jaminan terhadap milik tergugat, pada akhirnya jika barang milik tergugat dinyatakan dapat disita oleh Majelis Hakim, tergugat masih dapat mengelak akan harta benda miliknya. Pada prakteknya, walaupun jaksa dapat melakukan sita eksekusi terhadap harta benda milik terpidana, jaksa tidak dapat serta merta langsung melakukan sita eksekusi.

Menurut ketentuannya, berdasarkan S.E.M.A. nomor 4 tahun 1988 tentang Eksekusi Terhadap Hukuman Pembayaran Uang Pengganti dan peraturan Jaksa Agung Republik Indonesia No. B-020/A/J.A/04/2009 tentang Tata Cara Penyelesaian Denda dan Uang Pengganti dalam Perkara Tindak Pidana Korupsi, pelaksanaan putusan pengadilan yang berkekuatan hukum tetap guna pemenuhan uang pengganti harus melalui mekanisme gugatan pertada di pengadilan negeri. Namun, sebenarnya terhadap dua ketentuan di atas, dapat dikritisi bahwa pengajuan gugatan perdata di pengadilan negeri pada dasarnya menghabiskan waktu, tenaga, dan biaya lebih. Sehingga tidak mencerminkan proses peradilan yang cepat, sederhana dan biaya ringan. Padahal biaya yang dikeluarkan untuk biaya persidangan, sebenarnya dapat digunakan oleh tergugat (terpidana) untuk membayar pidana uang pengganti. 
Namun, karena negara melalui lembaga yudikatif sudah mengeluarkan ketentuan seperti S.E.M.A. nomor 4 tahun 1988 tentang Eksekusi Terhadap Hukuman Pembayaran Uang Pengganti, pada dasarnya terdapat pertimbangan mengenai pengajuan gugatan perdata untuk menagih pemenuhan pidana uang pengganti.

\section{Unsur Pasal 1365 KUHPerdata}

Perbuatan yang dilakukan masing-masing tergugat pada putusan mencerminkan teori perbuatan melawan hukum yang sebenarnya mirip dengan penjelasan yang diberikan oleh Prof. Wirjono Projodikoro, dimana maisngmasing tergugat dalam putusan tidak melakukan perbuatan aktif, melainkan perbuatan pasifnya yang mengakibatkan timbulnya kerugian. Prof. Wirjono P. mengatakan bahwa orang dengan berdiam diri saja dapat dikatakan melanggar hukum karena menurut hukum seharusnya orang itu bertindak. Akan tetapi orang yang diam saja, baru dapat dikatakan melakukan perbuatan hukum, kalau ia sadar, bahwa ia dengan diam saja adalah melanggar hukum, maka yang bergerak bukan tubuhnya seseorang itu, melainkan pikiran dan perasaannya. Oleh karena itu, analisa pada poin ini akan dibahas sebagai berikut:

\subsection{Ada Perbuatan}

Adanya perbuatan yang dimaksud dalam hal ini adalah perbuatan baik yang bersifat aktif maupun perbuatan yang bersifat pasif. Bersifat aktif maksudnya adalah dengan sengaja melakukan perbuatan yang menimbulkan kerugian pada orang lain. Sedangkan perbuatan yang bersifat pasif adalah melanggar suatu keharusan sehingga menimbulkan kerugian pada orang lain. Sebagaimana yang telah dijelaskan di atas, bahwa perbuatan pasif masingmasing tergugat dalam putusan gugatan perdata mencerminkan perbuatan pasif yang dikemukakan oleh Prof. Wirjono Projodikoro. Dengan demikian unsur adanya perbuatan dalam hal ini sudah terpenuhi.

\subsection{Perbuatan Tersebut Harus Melawan Hukum}

Pada unsur kedua dalam Pasal 1365 KUHPerdata, terdapat penjabaran mengenai kategori-kategori "perbuatan-perbuatan" yang melawan hukum, yaitu:

1. Bertentangan dengan hak subyektif orang lain;

Suatu perbuatan yang melanggar hak subyektif orang lain merupakan perbuatan melawan hukum apabila perbuatan itu secara langsung melanggar hak subyektif orang lain, dengan kata lain perbuatan tersebut disyaratkan adanya pelanggaran terhadap tingkah laku, yang didasarkan pada hukum tertulis maupun tidak tertulis yang seharusnya tidak dilanggar oleh pelaku dan tidak ada alasan pembenar menurut hukum. ${ }^{70}$

2. Bertentangan dengan kewajiban hukum si pelaku, atau

70 Moegni Djojodirdjo, Perbuatan Melawan Hukum, (Jakarta: Pradnya Paramita, 1979), hlm. 36. 
Kewajiban hukum (rechtsplicht) adalah kewajiban berdasarkan atas hukum. Dewasa ini yang dimaksud dengan hukum adalah baik hukum tertulis maupun tidak tertulis. Selain itu Sehingga, bertentangan dengan kewajiban hukum adalah perbuatan seseorang yang melakukan perbuatan yang bertentangan dengan keharusan dan larangan. ${ }^{71}$ Menurut Rosa Agustina dalam bukunya Law of Obligations, yang dimaksud dengan suatu tindakan atau kelalaian yang bertentangan dengan kewajiban hukum si pelaku adalah suatu tingkah laku yang bertentangan dengan sesuatu ketentuan undang-undang. Undang-undang dalam hal ini adalah semua peraturan yang sah dan dikeluarkan oleh instansi yang berwenang dan mempunyai daya ikat keluar. Menurut Setiawan, setiap ketentuan umum yang bersifat mengikat termasuk dalam pengertian "kewajiban hukum". Selain itu menurut Mochtar Kusumaatmadja, Oleh karena putusan berisi kaedah hukum, maka dapat dikatakan putusan pengadilan adalah hukum. Selain itu, menurut yurisprudensi Belanda yang dikutip oleh Setiawan, suatu perbuatan yang bertentangan dengan kewajiban hukum si pelaku, tidak dengan begitu saja merupakan perbuatan melawan hukum, selain itu masih disyaratkan: ${ }^{72}$

3. Bertentangan dengan kesusilaan (geode zeden), atau

Kaidah kesusilaan diartikan sebagai norma-norma sosial dalam masyarakat, sepanjang norma tersebut diterima oleh anggota masyarakat sebagai atau dalam bentuk peraturan-peraturan hukum yang tidak tertulis. Utrecht menulis bahwa yang dimaksudkannya dengan kesusilaan adalah semua norma yang ada di dalam kemasyarakatan, yang tidak merupakan hukum, kebiasaan, atau agama. ${ }^{73}$

4. Bertentangan dengan kepatutan yang berlaku dalam lalu lintas masyarakat terhadap diri dan orang lain.

Perbuatan yang bertentangan dengan kehati-hatian atau keharusan dalam pergaulan masyarakat yang baik ini atau yang disebut dengan istilah zorgvuldigheid juga dianggap sebagai suatu perbuatan melawan hukum. Pada pengertian ini manusia harus mempunyai tenggang rasa dengan lingkungannya dan sesama manusia, sehingga tidak hanya mementingkan kepentingan pribadi tetapi juga kepentingan orang lain sehingga dalam bertindak haruslah sesuai dengan kepatutan, ketelitian dan kehati-hatian yang berlaku dalam masyarakat.

Ketiga tergugat dalam putusan yang dianalisa telah melakukan perbuatan yang bertentangan dengan kewajiban hukum si tergugat. Kewajiban hukum

71 Moegni Djojodirdjo, Perbuatan Melawan Hukum, (Jakarta: Pradnya Paramita, 1979), hlm. 42.

72 Setiawan, Aneka Masalah Hukum dan Hukum Acara Perdata, cet. 1, (Bandung: Alumni, 1992), hlm. 253.

${ }^{73}$ Rosa Agustina, Perbuatan Melawan Hukum, cet I, (Jakarta: Program Pascasarjana Fakultas Hukum Universitas Indonesia, 2003), hlm. 39. 
(rechtsplicht) adalah kewajiban berdasarkan atas hukum. Dewasa ini yang dimaksud dengan hukum adalah baik hukum tertulis maupun tidak tertulis. Selain itu Sehingga, bertentangan dengan kewajiban hukum adalah perbuatan seseorang yang melakukan perbuatan yang bertentangan dengan keharusan dan larangan. ${ }^{74}$ Menurut Rosa Agustina dalam bukunya Law of Obligations, yang dimaksud dengan suatu tindakan atau kelalaian yang bertentangan dengan kewajiban hukum si pelaku adalah suatu tingkah laku yang bertentangan dengan sesuatu ketentuan undang-undang. Undang-undang dalam hal ini adalah semua peraturan yang sah dan dikeluarkan oleh instansi yang berwenang dan mempunyai daya ikat keluar. Menurut Setiawan, setiap ketentuan umum yang bersifat mengikat termasuk dalam pengertian "kewajiban hukum".

Selain itu menurut Mochtar Kusumaatmadja, oleh karena putusan berisi kaedah hukum, maka dapat dikatakan putusan pengadilan adalah hukum. Selain itu, menurut yurisprudensi Belanda yang dikutip oleh Setiawan, suatu perbuatan yang bertentangan dengan kewajiban hukum si pelaku, tidak dengan begitu saja merupakan perbuatan melawan hukum, selain itu masih disyaratkan: ${ }^{75}$

a. Bahwa kepentingan penggugat terkena atau terancam oleh pelanggaran (hukum) itu;

Berkaitan dengan perkara dalam putusan nomor nomor 22/Pdt.G/2010.PN.UNG; putusan nomor 116/Pdt.G/2013/PN.MTR; dan putusan nomor 24/Pdt.G/2013/PN.PRA, kepentingan penggugat yang terancam atas perbuatan tergugat ialah tidak terbayarnya uang pengganti, sehingga kerugian negara akan tetap timbul. Kerugian negara disini merupakan kerugian bangsa Indoneisa yang mencakup seluruh rakyat Republik Indonesia. Sehingga apabila tidak dibayar uang pengganti, kerugian negara akan terus timbul hingga uang pengganti itu dibayar lunas. Dengan demikian kepentingan penggugat yang terancam sudah terpenuhi.

b. Bahwa kepentingan penggugat dilindungi oleh kaidah yang dilanggar; Pasal 1365 KUHPerdata tidak menentukan dengan tegas adanya persyaratan yang menyatakan bahwa perbuatan itu melawan hukum bagi pihak yang dirugikan. Dengan kata lain, tidak ada pula peraturan yang menyatakana bahwa tidak melaksanakan pembayaran uang pengganti merupakan perbuatan melawan hukum. Persyaratan ini dapat ditemukan dalam ajaran relativitas. Secara singkat, ajaran relativitas dapat dirumuskan: bahwa seseorang yang melanggar kaidah hukum dan karenanya melakukan suatu perbuatan melawan hukum harus mengganti kerugian yang diakibatkan oleh perbuatannya, hanya apabila kaidah yang dilanggar itu bertujuan untuk melindungi kepentingan orang yang dirugikan tadi. Suatu kaidah hukum 1979), hlm. 42.

74 Moegni Djojodirdjo, Perbuatan Melawan Hukum, (Jakarta: Pradnya Paramita,

${ }^{75}$ Setiawan, Aneka Masalah Hukum dan Hukum Acara Perdata, cet. 1, (Bandung: Alumni, 1992), hlm. 253. 
dimaksudkan untuk melindungi suatu kepentingan tertentu. Pada putusan nomor 22/Pdt.G/2010.PN.UNG; putusan nomor 116/Pdt.G/2013/PN.MTR; dan putusan nomor 24/Pdt.G/2013/PN.PRA, kaidah yang dilanggar oleh tergugat ialah tergugat tidak mematuhi isi putusan pengadilan pidana terkait pemenuhan uang pengganti yang berkekuatan hukum tetap. Putusan pengadilan merupakan produk yudikatif, yang berisi kaidah atau peraturan hukum yang mengikat pihak-pihak yang bersangkutan atau terhukum, dan karenanya maka dapat dikatakan putusan pengadilan adalah hukum. Sehingga menjadi jelas bahwa kepentingan penggugat dilindungi oleh putusan pengadilan pidana yang telah berkekuatan hukum tetap dan dengan demikian kepentingan penggugat dilindungi oleh kaidah yang dilanggar sudah terpenuhi.

c. Bahwa kepentingan itu termasuk dalam ruang lingkup kepentingan yang dimaksud untuk dilindungi oleh ketentuan Pasal 1365 KUHPerdata (Pasal 1401 KUHPerdata Belanda);

Masih belum terdapat suatu kriteria yang jelas untuk menetapkan apakah suatu kepentingan termasuk dalam ruang lingkup kepentingan yang dimaksud untuk dilindungi oleh ketentuan Pasal 1365 KUHPerdata ataukah tidak. Berbeda halnya dengan apa yang dilakukan oleh ajaran relativitas, maka disini titik berat tidak diletakkan pada luasnya ruang lingkup perlindungan kepentingan yang diberikan oleh suatu kaidah hukum, melainkan diletakkan pada sifat/hakekat kepentingan yang terkena perbuatan melawan hukum. Dengan kata lain sifat kepentingan penggugat disini telah terancam dengan perbuatan melawan hukum itu. Berkaitan dengan putusan yang dianalisa, ketiga putusan pengadilan pidana yang berkekuatan hukum tetap dijatuhkan kepada masing-masing tergugat, yaitu 73/Pid.B/2002/PN.Ung atas nama Audy Murfi Hasibuan (tergugat); putusan nomor $718 \mathrm{~K} / \mathrm{Pid} / 1985$ atas nama Djamaluddin Saleh; dan putusan nomor $107 \mathrm{~K} / \mathrm{Pid} / 1994$ atas nama H. Lalu M. Ilham. Sehingga perbuatan membayar uang pengganti harus dibayar oleh ketiga tergugat dan apabila tidak dibayar, uang pengganti atau dalam syarat ini merupakan kepentingan yang terkena perbuatan melawan hukum. Dengan demikian kepentingan penggugat dalam perkara ini termasuk dalam ruang lingkup kepentingan yang dimaksud untuk dilindungi oleh ketentuan Pasal 1365 KUHPerdata sudah terpenuhi.

d. Bahwa pelanggaran kaidah itu bertentangan dengan kepatutan terhadap penggugat, satu dan lain hal dengan memperhatikan sikap dan kelakuan si penggugat itu sendiri;

Fakta bahwa seseorang telah melakukan pelanggaran terhadap suatu kaidah hukum, dapat menjadi faktor pertimbangan untuk menilai apakah perbuatan yang menimbulkan kerugian itu sesuai atau tidak dengan kepatutan yang seharusnya dimiliki seseorang dalam pergaulan dengan sesama warga masyarakat. Suatu putusan pengadilan pengadilan yang berkekuatan hukum tetap merupakan kaidah yang 
patut untuk ditaati. Berdasarkan Pasal 27 ayat (1) UUD 1945 yang menyatakan intinya bahwa warga negara Indonesia wajib untuk menjunjung hukum tanpa terkecuali. Oleh karena putusan pengadilan pidana yang berkekuatan hukum tetap adalah hukum bagi tergugat, sehingga tergugat harus taat dengan itu, maka perbuatan tidak melaksanakan pembayaran uang pengganti merupakan pelanggaran kaidah yang bertentangan dengan kepatutan. Dengan demikian syarat pelanggaran kaidah itu bertentangan dengan kepatutan terhadap penggugat pada putusan nomor 22/Pdt.G/2010.PN.UNG; putusan nomor 116/Pdt.G/2013/PN.MTR; dan putusan nomor 24/Pdt.G/2013/PN.PRA sudah terpenuhi.

e. Bahwa tidak terdapat alasan pembenar menurut hukum.

Adanya suatu alasan pembenar menurut hukum haruslah didalilkan serta dibuktikan oleh tergugat. Rutten menyebut alasan pembenar menurut hukum sebagai onrechtmatigheid-opheffende omstandigheid (keadaan yang meniadakan sifat melawan hukum). Contohnya adalah keadaan memaksa (overmacht), pembelaan terpaksa (noodweer), ketentuan perundang-undangan (wettelijk voorschrift), dan perintah jabatan (ambtelijk bevel). Berkaitan dengan putusan yang dianalisa, terhadap putusan nomor 22/Pdt.G/2010.PN.UNG tidak ditemukan alasan pembenar seperti keadaan memaksa, pembelaan terpaksa, ketentuan perundang-undangan, maupun perintah jabatan atas perbuatan pasif yang dilakukan tergugat. Sedangkan pada putusan nomor 116/Pdt.G/2013/PN.MTR, tergugat/wakilnya justru tidak hadir pada persidangan, padahal tergugat telah dipanggil secara sah dan patut. Ketidakhadiran tergugat bukan karena alasan yang sah, sehingga pada fakta persidangan tidak ditemukan adanya alasan pembenar. Terhadap putusan nomor 24/Pdt.G/2013/PN.PRA, diketahui bahwa tergugat sudah tidak memiliki pekerjaan sejak ia menjalani pidana pokok. Kesehatan tergugat juga tidak memungkinkan untuk mencari penghasilan guna membayar pidana uang pengganti. Namun alasan tersebut bukan merupakan suatu alasan yang dimaksud oleh dasar pembenar, sehingga hakim pada diktumnya tetap menghukum tergugat. Berdasarkan penjelasan di atas, karena tidak ditemukannya dasar pembenar dalam putusan, maka syarat tidak ada dasar pembenar telah terpenuhi.

Oleh karena kelima syarat di atas telah terpenuhi baik secara eksplisit dan implisit, maka dapat disimpulkan bahwa perbuatan tergugat yang bertentangan dengan kewajiban hukumnya itu, bersifat melawan hukum terhadap penggugat.

\subsection{Ada Kerugian}

Kerugian yang timbul akibat dari perbuatan pasif yang dilakukan masingmasing tergugat ialah dengan putusan pengadilan pidana yang beratasnamakan 
tergugat tidak dilaksanakan, dalam hal ini tidak membayar maupun melunasi pembayaran pidana uang pengganti, maka kerugian negara akan tetap timbul sampai kapanpun dan tidak terbayar atau tertutup hingga dibayar pidana uang pengganti tersebut seluruhnya. Pada pertimbangannya, hakim tidak mempertimbangkan mengenai kerugian yang timbul akibat perbuatan pasif tergugat, karena menurut hakim kerugian tersebut sudah jelas dengan adanya putusan nomor 73/Pid.B/2002/PN.Ung; putusan nomor $718 \mathrm{~K} / \mathrm{Pid} / 1985$; dan putusan nomor $107 \mathrm{~K} / \mathrm{Pid} / 1994$ yang telah berkekuatan hukum tetap.

Adapun kerugian yang ada diketiga putusan pengadilan pidana yang berkekuatan hukum tetap adalah bahwa tergugat tidak memenuhi kewajibannya untuk membayar uang pengganti sebesar Rp50.000.000, (putusan nomor 73/Pid.B/2002/PN.Ung); membayar uang pengganti sebesar Rp7.300.642,(putusan nomor718 K/Pid/1985); dan membayar uang pengganti sebesar Rp.37.900.000,- (putusan nomor $107 \mathrm{~K} / \mathrm{Pid} / 1994$ ) dari total kerugian negara yang timbul (Rp40.000.000,-.) . Sumber kerugian tersebut telah terbukti akan validitasnya yang tercantum di dalam putusan yang telah memperoleh kekuatan hukum tetap.

Dengan demikian, berdasarkan penjelasan si atas, unsur adanya kerugian dalam perbuatan yang dilakukan tergugat sudah terpenuhi

\subsection{Ada Hubungan Sebab Akibat Antara Perbuatan Melawan Hukum itu dengan Kerugian}

Teori Adequate Veroorzaking dari Von Kries mengajarkan bahwa perbuatan yang harus dianggap sebagai sebab dari akibat yang timbul adalah perbuatan yang seimbang dengan akibat dianggap cocok untuk diterapkan dalam perkara ini. Tidak melaksanakannya suatu putusan yang telah berkekuatan hukum tetap, dimana salah satu amarnya putusan tersebut adalah menghukum tergugat untuk membayar uang pengganti, maka secara langsung perbuatan pasif tersebut sudah mengakibatkan terjadinya kerugian. Dengan tidak dibayarkannya uang pengganti dalam putusan yang telah memperoleh kekuatan hukum tetap, maka sebenarnya kerugian negara tersebut akan terus timbul hingga uang pengganti dibayarkan oleh tergugat. Kenapa harus tergugat, karena putusan yang telah memperoleh kekuatan hukum tetap itu adalah atas nama tergugat dan dakwaan dalam putusan tersebut merupakan dakwaan tunggal. Dengan demikian sudah jelas bahwa perbuatan tergugat yang tidak memenuhi hukuman/sanksi uang pengganti akan tetap ada kerugian yang timbul hingga tergugat melunasi kewajibannya, sehingga unsur ada hubungan sebab akibat antara perbuatan melawan hukum itu dengan kerugian sudah terpenuhi.

\subsection{Kesalahan}

Terkait unsur adanya kesalahan dalam perbuatan melawan hukum, pada teorinya unsur kesalahan dipakai untuk menyatakan bahwa seseorang dinyatakan bertanggung jawab untuk akibat yang merugikan yang terjadi 
karena perbuatannya yang salah. Adapun unsur kesalahan dalam perbuatan melawan hukum akan terpenuhi, jika telah memenuhi salah satu di antara tiga syarat sebagai berikut, yaitu

1. Ada unsur kesengajaan;

Pada putusan nomor 22/Pdt.G/2010.PN.UNG, tergugat secara sadar keberatan untuk membayar pidana uang pengganti. Bentuk penolakan tersebut bukan merupakan suatu alasan pembenar dalam perbuatan pasif tergugat. Sehingga pada perkara ini tergugat telah sengaja untuk tidak membayar uang pengganti. Lain hal dengan putusan nomor 24/Pdt.G/2013/PN.PRA yang tidak ditemukan unsur kesengajaan, karena melihat kondisi tergugat yang bisa dikatakan sudah tidak mampu, unsur kesengajaan tidak terbukti dalam perbuatan pasif tergugat

2. Ada unsur kelalaian;

Pada kelalaian tidak ada niat dalam hati pelaku untuk menimbulkan kerugian. Niat atau sikap mental tersebut tidak menjadi penting, yang menjadi penting adalah sikap lahiriah dan perbuatan yang dilakukan, tanpa terlalu mempertimbangkan apa yang ada didalamnya. Pada ada unsur kelalaian ini tercermin pada perbuatan pasif tergugat (H. Lalu M. Ilham) di putusan nomor 24/Pdt.G/2013/PN.PRA, karena pada dasarnya ia tidak berniat untuk tidak membayar. Tergugat dalam perkara ini tidak membayar uang pengganti karena ketidakmampuannya untuk menghasilkan sejumlah uang, karena keterbatasan kesehatan yang dialami.

3. Tidak ada alasan pembenar atau alasan pemaaf, seperti overmacht, membela diri, dan lain-lain.

Bahwa dalam melakukan perbuatan pasif di perkara ini, tergugat dengan perbuataannya tidak ditemukan adanya alasan pembenar dan pemaaf, maupun adanya unsur keterpaksaan (overmacht) dari perbuatan yang dilakukan tergugat, justru tergugat dalam perkara secara sadar hanya mengakui keberatan untuk melakukan pembayaran uang pengganti. Berkaitan dengan putusan yang dianalisa, tidak adanya alasan pembenar, pemaaf terdapat dalam putusan nomor 116/Pdt.G/2013/PN.MTR. Tergugat dalam putusan ini tidak mengajukan alasan berupa alasan pembenar maupun pemaaf karena ketidakhadirannya dalam persidangan

\section{Penutup}

\section{Kesimpulan}

Dasar pengajuan gugatan Perbuatan Melawan Hukum yang berlaku selama ini di Indonesia mengacu pada peraturan perundang-undangan, khususnya Pasal 1365 KUHPerdata. Suatu perbuatan yang bertentangan dengan asas kepatutan, asas ketelitian dan asas kehati-hatian juga termasuk dalam perbuatan melawan hukum. Putusan pengadilan pidana tentang pelaksanaan uang pengganti dalam perkara pidana korupsi berdasarkan UU No. 3 Tahun 1971 yang telah berkekuatan hukum tetap dapat menjadi dasar 
gugatan perbuatan melawan hukum (onrechtmatige daad). Dalam hal tidak melakukan pembayaran uang pengganti berdasarkan putusan yang telah berkekuatan hukum tetap (putusan nomor 73/Pid.B/2002/PN.Ung tanggal 23 Oktober 2002, putusan nomor $718 \mathrm{~K} / \mathrm{Pid} / 1985$ tanggal 25 Juni 1985, dan putusan nomor $107 \mathrm{~K} / \mathrm{Pid} / 1994$ tanggal 29 Mei 1994) dapat menjadi dasar pengajuan gugatan perbuatan melawan hukum (onrechtmatige daad). Dasar pengajuan gugatan terdapat dalam Peraturan Jaksa Agung Republik Indonesia No. B-020/A/J.A/04/2009 tentang Tata Cara Penyelesaian Denda dan Uang Pengganti dalam Perkara Tindak Pidana Korupsi yang menunjukan bahwa tidak memenuhi putusan pengadilan pidana yang telah berkekuatan hukum tetap merupakan suatu perbuatan melawan hukum, karena apabila tidak dilaksanakan, maka dapat diajukan gugatan perdata.

\section{Saran}

Jaksa saat mengajukan gugatan perdata sebagai melakukan upaya hukum terkait pemenuhan pidana uang pengganti, seyogyanya sudah mengetahui terlebih dahulu harta benda milik terpidana yang ingin digugat untuk pemenuhan pidana uang pengganti. Apabila hal tersebut tidak dilakukan dan harta benda milik terpidana tidak dituntut sebagai jaminan pemenuhan pidana uang pengganti dalam gugatan, walaupun menang pada akhirnya, jaksa tetap tidak dapat melakukan sita eksekusi, sehingga upaya hukum tersebut tidak efektif. Pada pelaksanaan pidana uang pengganti terhadap tindak pidana korupsi yang dilakukan sebelum tahun 1999, sebaiknya terdapat Standar Operasional Prosedur yang jelas yang berbentuk peraturan, dalam hal ini bisa dalam pentuk Peraturan Jaksa Agung terkait pelaksanaan putusan pengadilan, khususnya mengenai pidana uang pengganti.

Pada pengajuan gugatan perdata terkait untuk menagih pembayaran uang pengganti, Jaksa Pengacara Negara selaku penggugat sebaiknya merumuskan dasar gugatan yang lebih lengkap, seperti mencantumkan S.E.M.A. nomor 4 tahun 1988 tentang Eksekusi Terhadap Hukuman Pembayaran Uang Pengganti dan peraturan Jaksa Agung Republik Indonesia No. B-020/A/J.A/04/2009 tentang Tata Cara Penyelesaian Denda dan Uang Pengganti dalam Perkara Tindak Pidana Korupsi. Jadi tidak hanya berdasar pada Pasal 1365 KUHPerdata dan Pasal 27 ayat (1) UUD1945 saja. Sebaiknya terdapat cara lain untuk menagih pidana uang pengganti kepada terpidana, selain mekanisme pengajuan gugatan perdata ke pengadilan negeri. Oleh karena dengan diajukannya gugatan ke pengadilan, uang yang dikeluarkan tergugat untuk menjalani persidangan dapat digunakan/dialihkan untuk pembayaran pidana uang pengganti. Selain jangka waktu yang diperlukan akan semakin panjang dan pengembalian uang negara akan menjadi semakin lama dan tidak jelas. 
Putusan Pengadilan Pidana Sebagai dasar Pengajuan Gugatan PMH, Sri Laksmi Anindita

\section{Daftar Pustaka}

\section{Buku}

Agustina, Rosa. et al. Hukum Perikatan (Law of Obligations). Bali: Pustaka Larasan, 2012.

Agustina, Rosa. Perbuatan Melawan Hukum. cet I. Jakarta: Program Pascasarjana Fakultas Hukum Universitas Indonesia, 2003.

Badrulzaman, Mariam Darus. KUH Perdata Buku III Hukum Perikatan dengan penjelasan. Bandung: Alumni, 1996.

Djojodirdjo, Moegni. Perbuatan Melawan Hukum. Jakarta: Pradnya Paramita, 1979.

Fuady, Munir. Perbuatan Melawan Hukum (Pendekatan Kontemporer). Bandung: PT Citra Aditya Bakti, 2002.

Harahap, M. Yahya. Hukum Acara Perdata Tentang Gugatan, Persidangan, Penyitaan, Pembuktian, dan Putusan Pengadilan. cet. III. Jakarta: Sinar Grafika, 2005.

Kusumaatmadja, Mochtar dan Arief Sidharta. Pengantar Ilmu Hukum. cet. 2. Bandung: PT. Alumni, 2009.

Mamudji, Sri. et.al. Metode Penelitian dan Penulisan Hukum. Jakarta: Badan Penerbit Fakultas Hukum Universitas Indonesia, 2005.

Mertokusumo, Sudikno. Hukum Acara Perdata Indonesia. Yogyakarta: Liberty, 1993.

Miru, Ahmadi. Hukum Perdata Materiil dan Formil. Jakarta: United States Agency for International Development (USAID), 2013.

Mulyadi, Lilik. Hukum Acara Perdata: Menurut Teori \& Praktek Peradilan Indonesia. Jakarta: Djambatan, 1999.

Nasir, Muhammad. Hukum Acara Perdata. cet. II. Jakarta: Djambatan, 2005.

Prodjodikoro, Wirjono. Perbuatan Melanggar hukum. Bandung: Sumur, 1993.

Setiawan. Aneka Masalah Hukum dan Hukum Acara Perdata. cet. 1. Bandung: Alumni, 1992.

Supomo. Hukum Atjara Perdata Pengadilan Negeri. Jakarta: Fasco Djakarta, 1958.

Syahrani, Riduan. Hukum Acara Perdata di Lingkungan Peradilan Umum. cet. I. Jakarta: Pustaka Kartini, 1998.

Tim Pengajar Pengantar Hukum Indonesia. Materi Ajar Pengantar Hukum Indonesia. Depok: Fakultas Hukum Universitas Indonesia, 2012.

\section{Peraturan Perundang-undangan}

- Reglemen Indonesia yang Diperbaharui [Herziene Indonesisch Reglement], Stb. 1941 No. 44. Disusun oleh M. Karjadi. Bogor: Politeia, 1979. . Undang-Undang Pemberantasan Tindak Pidana Korupsi, UU No. 3 Tahun 1971, LN No. 19 Tahun 1971. . Kitab Undang-undang Hukum Perdata (Bugelijk Wetboek). 
Diterjemahkan oleh R. Subekti dan R. Tjitrosidibio. Jakarta: Pradnya Paramita, 1976. . Kitab Undang-undang Hukum Pidana, cet. 21. Diterjemahkan oleh Moeljatno. Jakarta: PT Bumi Aksara, 2001. . Undang-undnag Dasar 1945.

Jaksa Agung Republik Indonesia. Surat Edaran Jaksa Agung RI tentang Penyesuaian Kode Formulis Berita Acara Administrasi Perkara Pidana, Surat Edaran Jaksa Agung RI Nomor: SE-009/A/JA/08/2015.

Mahkamah Agung. Surat Edaran Mahkamah Agung tentang Eksekusi Terhadap Hukuman Pembayaran Uang Pengganti, SEMA No. 4 Tahun 1988.

\section{Artikel/Jurnal}

Anindita, Sri Laksmi. "Keyakinan Hakim Dalam Menjatuhkan Putusan Perkara Pidana," dalam Praperadilan dan Perkembangannya Dalam Hukum Acara Pidana Indonesia. ed. Disriani Latifah Soroinda. Depok: Badan Penerbit FHUI, 2016.

\section{Internet}

Ari, Ivan. "Gugurnya Suatu Gugatan." <http://www.hukumacaraperdata.com/gugurnya-suatu-gugatan/>, diakses pada 3 Juni 2016.

Code Civil. Article 1382. $<$ https://www.legifrance.gouv.fr/affichCodeArticle.do?cidTexte=LEGI

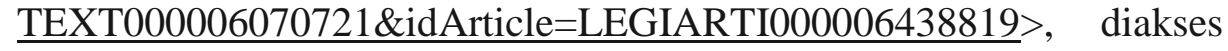
pada 10 Mei 2016.

"Pengertian Eksekusi Definisi Sumber Hukum Perdata dan Putusan Pengadilan yang Berkekuatan Hukum Tetap," <http://www.landasanteori.com/2015/09/pengertian-eksekusi-definisisumber.html $>$, diakses pada 31 Mei 2016. 